\title{
AZ ÖNAKADÁLYOZÁS PSZICHOLÓGIÁJA
}

\author{
TÖRÖK LILLA ${ }^{1}$ - SZABÓ ZSOLT PÉTER ${ }^{2,3}$ - BODA-UJLAKY JUDIT ${ }^{1}$ \\ ${ }^{1}$ Testnevelési Egyetem, Pszichológia és Sportpszichológia Tanszék \\ ${ }^{2}$ Eötvös Loránd Tudományegyetem, Szociálpszichológia Tanszék \\ ${ }^{3}$ Pécsi Tudományegyetem, Szociál- és Szervezetpszichológia Tanszék
}

E-mail: torok.lilla@tf.hu

Beérkezett: 2015. január 7. - Elfogadva: 2015. október 23.

\begin{abstract}
Önakadályozásnak nevezzük azt a jelenséget, amikor bizonyos körülmények között adott személyiségváltozókkal jellemezhetố egyének fontos teljesítményhelyzetek elótt saját maguk által felállított akadályokkal hátráltatják az eredményességüket. A tanulmány elején pontosan definiáljuk az önakadályozást, elhelyezzük a pszichológiai elméletek, valamint a szociálpszichológiai rokon fogalmak között. Az önakadályozás két formáját elkülönítve, a viselkedéses önakadályozást és a mondott akadályokat részletesen tárgyaljuk. Röviden kitérünk a jelenség hátterében meghúzódó motivációkra. A tanulmány elemzi az önakadályozást befolyásoló tényezóket, amelyeket két dimenzió - személyhez vagy környezethez köthetố, serkenti vagy gátolja - mentén osztályoz. Az önakadályozás következményeit elönyös és hátrányos megosztásban csoportositva vitatjuk meg. Az önakadályozás mérési lehetôségeinél bemutatjuk a kérdốves és kisérleti módszereket. Az összefoglalás során kitérünk az eddig elvégzett elméleti és empirikus munka értékelésére, a gyakorlati alkalmazás kérdéseire, a magyar vonatkozásokra és a kutatási nehézségekre.
\end{abstract}

Kulcsszavak: önakadályozás, énvédô mechanizmusok, benyomásalakítás

\section{AZ ÖNAKADÁLYOZÁS JELENSÉGÉNEK ELMÉLETI HÁTTERE}

Önakadályozásnak (self-handicapping) nevezzük azt a jelenséget, amikor valaki fontos teljesítményhelyzetbe kerülve saját maga által felállított akadályokkal hátráltatja eredményességét. A jelenségre jó példa, amikor a vizsgázó mértéktelen szórakozásba kezd a vizsgát megelốzó éjjel, avagy amikor a sportoló sérülésrôl vagy betegségrôl panaszkodik a versenyhelyzetet megelôzoóen. Az önakadályozás jelensége a kilencvenes évektôl kezdve élénk érdeklődés tárgya a nemzetközi szakirodalomban, hiszen az egyéni teljesítmény, a tömegból való kiemelkedés, az interperszonális összehasonlítások egyre nagyobb hangsúlyt kapnak. A jelenségnek ugyan vannak adleri gyökerei (aki szerint a be- 
tegségek és tünetek generálása felhasználható a törékeny én védelmében; Adler, 1929; DeGree és Snyder, 1985), mégis a fogalom megszületése 1978-ra datálható, amikor Jones és Berglas empirikus vizsgálatukban azt találták, hogy teljesítményhelyzetbe kerülve a kudarctól tartó vizsgálati személyek egy teljesítménynöveló gyógyszer (Actavil) helyett teljesítménygátló gyógyszer (Pandokrin) bevétele mellett döntöttek (Berglas és Jones, 1978; Jones és Berglas, 1978). Ezek az eredmények kérdéseket vetettek fel Festinger (1954) társas összehasonlítás elméletének alaptézisét illetôen, miszerint az emberek alapvetố tendenciája az a törekvés, hogy pontos, hiteles és diagnosztikus viszszajelzést kapjanak környezetüktôl képességeiket illetôen, hiszen láthatóan e helyett bizonyos helyzetekben kifejezetten kerülik az effajta információkat. Eredményeik nyomán Jones és Berglas (1978) definíciója szerint az önakadályozás olyan cselekvés vagy teljesítményhelyzet-választás, amely növeli a kudarc externalizálásának (önfelmentés) és a siker internalizálásának esélyét. Az önakadályozás segítségével még a feladat végrehajtás elôtt létrehozható egy „gyôztes-gyôztes” helyzet, hiszen a kudarc esetén annak okait külsô, instabil, kontrollálható, specifikus okokban lehet megtalálni, míg a sikert a gátló tényezôket is legyôzố kimagasló képességeknek lehet tulajdonítani. Az ilyen típusú oktulajdonítások, attribúciók azért elônyösek, mert mind kudarc, mind siker esetében segítenek fenntartani a motivációt és a pozitív érzelmeket (Weiner, 1985). Az önakadályozó az akadály segítségével elhomályosítja a kapcsolatot a képességei és a teljesítmény között, és olyan módszert használ, amivel kudarc esetében védeni, siker esetében pedig erôsíteni tudja az önmagáról kialakított pozitív képet és társas megítélést.

A jelenség többféle elméleti keretben tárgyalható, de mivel alapvetôen oksági következtetéseken keresztül fejti ki hatását, így elsôsorban a kognitív szociálpszichológia, az attribúciós irodalom tárgykörébe tartozik.

A motivációs bázisú attribúciós torzítások közül az önkiszolgáló torzítás (Brown, 1991) és az önakadályozás közti hasonlóság szembeötlő, több kutatásban tévesen össze is mossák óket (pl. Nordbotten, Abrahamsen és Karlsen, 2012; Smith, Snyder és Handelsman, 1982). Az önkiszolgáló torzítás lényege az egyén minél kedvezóbb színben való feltüntetése egy adott teljesítményhelyzetet követően (a sikert a képességek, a kudarcot a külsố körülmények számlájára írni). Az önakadályozást és az énkiszolgáló torzításokat azonban elkülöníti az, hogy míg az utóbbi a teljesítményszituáció elốtt (a priori), addig az elóbbi az után (a posteriori) történik (McCrea, Myers és Hirt, 2009). Jones és Berglas (1978) az önakadályozás jelenségének magyarázatához kezdettôl fogva felhasználta a Kelley (1971) kovarianciaelméletében megfogalmazott leszámítolás és felnagyítás elveit. A leszámítolás elve szerint egy adott kimenet esetében egy rendelkezésünkre álló erôs ok leszámolja az egyéb kisebb erejú magyarázatokat. Erre példa, amikor az ittasan okozott autóbaleset esetében a baleset kizárólagos okaként az alkoholfogyasztást nevezzük meg, leszámolva ezzel a többi tényezôt (csúszós út, rossz látási viszonyok stb.), amelyek szintén hozzájárultak a balesethez. A felnagyítás elve szerint az egyén egy adott ok szerepét erôteljesebbnek tekinti, ha az általa okozott következmény valamilyen ellentétes, gátló tényezô jelenléte ellenére is elôállt. Például a sikeres végrehajtást hátráltató tényezô jelenlétében a képesség szerepét erôteljesebb okozóként tünteti fel. Erre példa, amikor a felnốtt korosztályos sportversenyt egy serdülôkorú versenyzô nyeri meg, hiszen így a képességét még kiemelkedóbbnek 
tekintjük, mintha a saját korosztályában győzött volna. Az önakadályozás egyszerre kovácsol hasznot mindkét elvbôl: a kudarccal végzôdô szituációban az akadály leszámolja a képességek szerepét, míg az akadály ellenére is előálló siker felnagyítja az egyéni képességeket.

Flamm (2007) Atkinson (1964) teljesítménymotivációs elméletének keretében tárgyalja az önakadályozást. A szerzô szerint az egyének elkerülő stratégiát használnak azokban a teljesítményhelyzetekben, amelyekben a kudarc eshetôsége fennáll (kudarckerülés), míg pozitívan motiváltak, érdeklődók, és a jó feladat-végrehajtásra vonatkozó aktív törekvés jellemzi ôket, ha sikerre van kilátás (sikerorientáció). Atkinson (1964) szerint a magas kudarckerüléssel jellemezhető egyének igyekeznek elkerülni a képességeiket illetô diagnosztikus információkat, és irreálisan alacsony vagy magas célokat választanak (vö. Flett, Blankstein, Hewitt és Koledin, 1992; Greenberg, 1985; Schultheissn és Brunstein, 2000).

Covington (1992) énérték (self-worth) elmélete szerint az egyén „értékessége” gyakran az elért teljesítménye mentén mérhetô, a legfőbb emberi törekvés pedig az (ön) elfogadáskeresése. Az egyén tehát hajlamos mindent megtenni azért, hogy önmagáról pozitív képet alakítson ki, és tartson fenn, ezért aztán az értékességét fenyegetô helyzetekben különféle védekezô mechanizmusokhoz nyúl. Covington (1992) szerint ilyen védekezó mechanizmus az önakadályozás is.

Coudevylle, Martin Ginis és Famose (2008) Bandura szociál-kognitív elméletének (1986) lencséjén át közelítenek az önakadályozáshoz. A szociális-kognitív tanuláselméletek szerint az emberi motivációt, és ennek következtében a cselekvést és a teljesítményt nagymértékben befolyásolják az előzetes elképzelések. Ezek magukban foglalják a várakozások három fajtáját: a szituációkimenetellel kapcsolatos várakozások, a cselekvés eredményével kapcsolatos elvárások és az észlelt énhatékonyság. A szerzôk szerint azok, akik akadályozzák teljesítményüket, azért vállalnak ekkora kockázatot, mert meg vannak gyôzoôdve az elkövetkezendố kudarcról (pl. Pyszczynski és Greenberg, 1983). Ennek megfelelôen, akik szerint kicsi, vagy relatíve nincs esély a sikerre, kevesebb erôfeszítést fordítanak a közelgô, az egó szempontjából jelentôs feladatra, mint azok, akik sikert remélnek. Amint tehát a szociál-kognitív elmélet is gondolja, azok a maladaptív viselkedésformák, mint az erőfeszítés hiánya, elsôsorban egy bizonytalan szituációban jelennek meg, amikor a jó teljesítmény/képesség visszajelzés elvárása alacsony szintú.

Freud 1920-ból származó halálösztön (Thanatos) fogalmából kiindulva Baumeister és Scher (1988) egészséges személyeket illetôen azonosítottak és kategorizáltak bizonyos önkárosító viselkedéseket (self-defeating behaviours). Összefoglaló tanulmányukban ezeket a viselkedéseket három kategóriába sorolták, melyek a szándékos önkárosítási formák (akaratlagos és kívánatos; pl. hibázásra való törekvés), rövid távú elônyök és hosszú távú költségek közti kiegyezések (akaratlagos, de nem kívánatos; pl. drogabúzus, egészség elhanyagolása), valamint nem kívánatos eredményre vezetô stratégiák (nem akaratlagos és nem kívánatos; túlzásba vitt kitartás, tanult tehetetlenség). A szerzôk az önakadályozást kiegyezésként (tradeoff-ként) értelmezik, ahol két vágyott cél verseng egymással: sikeresen végrehajtani egy feladatot vs. maximális attribúciós elônyöket élvezni. A kutatók szerint az önakadályozó egyén hosszú távú hátrányokat (alulteljesítés, alkoholizmus, drogabúzus) vállal azonnali elônyökért (védelem 
a kudarc ellen) cserébe. Ugyanakkor az önakadályozás azonnali hátrányai is nyilvánvalóak (a sikeres teljesítés kockáztatása/feláldozása).

Az önakadályozás és a klinikai pszichológia lehetséges kapcsolatára mutat rá a DSM-III-R (APA, 1987) mellékletében megvitatásra került 301.90 kóddal jelzett mazochista vagy önsorsrontószemélyiségzavar (self-defeating personality disorder). Az ebbe a diagnosztikus kategóriába sorolt személyek a számukra rendelkezésre álló jobb lehetôségek ellenére következetesen olyan választásokat hoznak, amelyek rossz bánásmódhoz, csalódáshoz, szenvedéshez vezetnek. Schill, Morales, Beyler, Tatter és Swigert (1991) empirikus vizsgálatukban valóban kapcsolatot találtak az önsorsrontó személyiség és az önakadályozási hajlam között. Fontos megjegyezni azonban, hogy az önsorsrontó, mazochista személyiségzavar soha nem került be hivatalosan a DSM-be, és a kategóriával kapcsolatos politikai és fogalmi viták - elsôsorban a diagnosztikus kategória összekapcsolódása a családon belüli erôszakkal és az áldozatok hibáztatásával - miatt az 1994-ben megjelent DSM-IV-ben már a mellékletnek sem volt a része.

$\mathrm{Az}$ önakadályozás közvetlen okait feltáró, úgynevezett proximatív magyarázatok mellett az evolúciós pszichológiában megjelent egy távoli, úgynevezett ultimatív magyarázat a jelenségre: az állatvilágban széles körben megfigyelhetô Zahavi hátrányelv (handicap principle; Zahavi és Zahavi, 1997) szerint olyan nagy ráfordítást igényélő - és a ráfordítás miatt hátrányos - morfológiai és viselkedéses jellegeket akkor érdemes kialakítani, ha azok máshol (például a szaporodási sikerben) megtérülnek. Például a pávakakas farkdísze amellett, hogy figyelemfelhívó, jelentôsen megnehezíti a mozgást, így a ragadozók elôl való menekülést, tehát viselôi közül csak a legjobbak élik túl.

Az önakadályozás fogalmának pontos meghatározásakor fontos az önakadályozást más hasonló, rokontermészetû fogalmaktól megkülönböztetni. Ilyen például a kifogáskeresés, de ez a már korábban említett önkiszolgáló torzításhoz hasonlóan a teljesítményhelyzetet nem megelôzi, hanem követi (Doliński, Szmajke és Gromski, 1990).

Szükséges az önakadályozás elhatárolása a védekezô pesszimizmustól. A pesszimizmust irreálisan alacsony elvárások jellemzik. Az egyén a legrosszabb eshetôségre felkészülve tekint az elkövetkezendô teljesítményhelyzetre a korábban megtapasztalt sikerélmények ellenére is (Norem és Cantor, 1986). Az önakadályozás és a pesszimizmus között a legfontosabb különbség, hogy míg az önakadályozás úgy módosítja a kudarc jelentését, hogy az okot eltereli a képességek felôl változékonyabb faktorok felé, addig a védekezô pesszimizmus esetén az egyén önmagát edzi a kudarcra, alacsony és biztonságos standardokat állít (Martin, Marsh és Debus, 2003).

A téma szempontjából fontos fogalom a becsapás egy speciális formája, a sandbagging. Az eredeti kifejezés arra vonatkozott, amikor valaki egy homokkal teli zsákkal (sandbag) üti le az ellenfelét,így jutva jogosulatlan előnyhöz. Késôbb a kifejezés értelme változott és ma a sandbagging egy manipuláción alapuló negatív szelf reprezentációs stratégiát jelent, melynek során az egyén értéktelen ellenfélnek, kevésbé kompetensnek vagy inkompetensnek mutatja magát, hogy mások erófeszítését és/vagy védekezését csökkentse (Shepperdés Socherman, 1997). Az önakadályozással számos közös vonása van (pl. negatív szelf reprezentáció, közönség meggyôzése a közelgó rossz teljesítményrôl), azonban míg a sandbagginget használók képességeik gyengeségéról számolnak be (vagy demonstrálják azt), az önakadályozók éppen ezt (vö. ku- 
darcot követô képességbeli attribúciókat) igyekeznek elkerülni. Szintén különbség, hogy míg az önakadályozókra a képességeikben való bizonytalanság jellemzô, addig a sandbagginget választóknál ez nincs így (Gibson és Sachau, 2000).

Az önakadályozással kapcsolatban felmerül a kérdés, hogy vonásról van-e szó vagy szituációtól függố állapotról. Már Berglas és Jones (1978) úttörô tanulmányukban úgy fogalmaznak, hogy „kétségtelen, hogy néhány ember hajlamosabb önakadályozó stratégiákhoz nyúlni, mint mások” (406). A kezdeti idószakban elvégzett kutatások így elsôsorban a vonásalapú megközelítést képviselték (például Rhodewalt, Saltzman és Wittmer, 1984; Strube, 1986). Harris és Snyder (1986) tanulmányukban egyenesen úgy érvelnek, hogy az önakadályozás következtében a valódi képességek akár egy életen keresztül rejtve maradhatnak. A vonásként mért önakadályozás összefüggést mutat globális személyiségjellemzókkel: pozitív kapcsolatban van a neuroticitással és negatív kapcsolatban a lelkiismeretességgel (Bobo, Whitaker és Strunk, 2013). Egyes feltevések szerint az önakadályozás nem csupán kapcsolatban áll a „két nagy” vonással, hanem közvetítô szerepet is játszik azok kapcsolatában. A szerzók értelmezésében az alacsony szintû feladatbevonódás esetében (alacsony lelkiismeretesség) ugyanis, az önakadályozó személy gátló tényezóket gördít a siker útjába, ezzel azonban növeli mind a kudarc, mind a kudarccal járó negatív affektusok (magas neuroticitás) megjelenésének valószínúségét. Utóbbi viszont növeli a késôbbi feladattal kapcsolatos tevékenységek elkerülésének mértékét (alacsony lelkiismeretesség; Ross, Canada és Rausch, 2002).

A vonásjellegú megközelítés óvatosabb verziója szerint az önakadályozás nem globális, hanem csupán a személy életének egy adott területére vonatkozik, például a tanulásra, sportolásra, munkára (Martin és Brawley, 1999; Schwinger, 2013). Az állapotként értelmezett önakadályozás a környezeti kontextust helyezi a középpontba azt állítván, hogy a szituáció bizonyos jellemzôi növelik az önakadályozás használatának valószínúségét. Az önakadályozást így értelmezô kutatások elsôsorban ezeket a szituációs tényezôket kívánják azonosítani (Elliot, Cury, Fryer és Huguet, 2006; Self, 1990; Shepperd és Arkin, 1989a).

Az önakadályozás fogalmának tisztázását követôen a tanulmány úgy épül fel, hogy elóbb bemutatjuk az önakadályozás formáit, majd az önakadályozást megalapozó motivációkat, a befolyásoló faktorokat és a következményeket. Tanulmányunkban kitérünk a mérés formáira, az esetleges problémákra és az eddig kevésbé használt mérési lehetôségekre. Az összegzésben sort kerítünk az eddig elvégzett elméleti és empirikus munka értékelésére, a gyakorlati alkalmazás kérdéseire, a magyar vonatkozásokra és a kutatási nehézségekre.

\section{AZ ÖNAKADÁLYOZÁS FORMÁI}

Az önakadályozás kutatásának kezdetén (Berglas és Jones, 1978; Tucker, Vuchinich és Sobell, 1981; Weidner, 1980) elsôsorban valamely szer hatása szolgált akadályként (gyógyszer, alkohol), azonban 1982-tôl kezdôdôen megszaporodott azoknak a publikációknak a száma, ahol az önakadályozás nem cselekvésekként, hanem verbális kinyilatkoztatásokként, kijelentésekként jelenik meg (Baumgardner, Lake és Arkin, 
1985; Smith és mtsai, 1982). Elsóként Arkin és Baumgardner (1985) tett különbséget az önakadályozás kétféle megnyilvánulása között, amelyeket szerzett (acquired) és kijelentett (claimed) akadályoknak (obstacles) nevezett. Ezt a fogalmi elkülönítést pontosítva és megszilárdítva Leary és Shepperd (1986) nyomán nevezzük a szerzett akadályokat viselkedéses önakadályozásnak (behavioral self-handicapping), míg a kijelentett gátló tényezóket mondott akadályoknak (self-reported handicaps). Míg az elôbbiek nyílt, önakadályozó cselekvések a végrehajtás elôtt, addig az utóbbiak verbális kijelentések a teljesítményt hátráltató tényezô(k) jelenlétérôl. Az elkülönítés több szempontból fontos, hiszen nemcsak az önakadályozóra vonatkozó veszélyeiben különböznek, de elképzelhetô, hogy más-más szituációs elôzményekkel is rendelkeznek, illetve különbözô faktorok motiválják a kettốt (Coudevylle és mtsai, 2008a), tehát a fogalmi elkülönítés empirikus alapokon is indokolt.

Ahogy arra már utaltunk, a téma kutatása a viselkedéses akadályok vizsgálatával indult (Berglas és Jones, 1978). Ezek a megnyilvánulások általában jobban láthatóak, kontrollálhatóbbak, és közvetlenebbül kötốdnek a teljesítményhez, mint a mondott akadályok (Hirt, Deppe és Gordon, 1991; Leary és Shepperd, 1986). A viselkedéses önakadályozás költségesebb, mint a kijelentésekkel manipuláló párja, hiszen ezekkel a cselekvésekkel az egyén valóban csökkenti a sikeres teljesítmény valószínúségét. Ugyanakkor célját tekintve hatékonyabb is, mert kevésbé vitatható, és mindenki számára nyilvánvaló a gátló tényezô jelenléte. Viselkedéses önakadálynak számít például a gyógyszer hatása vagy mellékhatása (Berglas és Jones, 1978), az alkoholfogyasztás (Higgins és Harris, 1988; Tucker és mtsai, 1981), elérhetetlen célok (Greenberg, 1985) vagy nem megfelelô, elônytelen környezeti feltételek választása (Rhodewalt és Davison, 1986), és ide tartozik az elégtelen mennyiségú gyakorlás is (Tice és Baumeister, 1990). Szintén ide sorolható a teljesítményhelyzet elôtt az erófeszítés nem növelése (Rhodewalt és mtsai, 1984), vagy akár csökkentése (Thompson és Richardson, 2001), aminek krónikus megjelenése az alulteljesítés (Nurmi, Onatsu és Haavisto, 1995; Rhodewalt, 1990). Specifikus formája lehet a viselkedéses önakadályozásnak a mások erôsítése (other-enhancement) jelenség is (Shepperd és Arkin, 1991). A szerzôk szerint azzal, hogy erôsítjük az összehasonlítás tárgyául szolgáló egyént, esetleg ellenfelet (pl. a sajátunkénál jobb körülmények választása számukra, amennyiben összehasonlításra számítunk, és bizonytalan a végkimenetel), az önakadályozáshoz hasonló attribúciós előnyöket élvezhetünk.

A mondott akadályok esetében az önakadályozó egyén csupán a gátló tényezô jelenlétérôl tesz kijelentést, és nem feltétlenül van meggyôzôdve az elkövetkezendô kudarcról. A közelgố feladatot éppen ezért nem szabotálja veszélyes viselkedésformákkal, csak az önakadályozás okozta attribúciós kétértelmúségre épít (Coudevylee és mtsai, 2008a). Olyan akadályokra vonatkozó kijelentések tartoznak ide, mint a fizikai tünetek vagy betegség jelenléte (Mello-Goldner és Jackson, 1999; Smith, Snyder és Perkins, 1983), a fájdalom eltúlzása (Uysal ésLu, 2010), vagy éppen szorongásra (Smith és mtsai, 1982; Snyder, Smith, Augelli és Ingram, 1985), hangulatra (Baumgardner, Lake és Arkin, 1985) történố hivatkozás.

A kutatások tükrében fellelhetô egy szorosabban a mondott akadályokhoz kapcsolódó, mégsem teljesen azt fedô önakadályozó forma, amelynek során az egyénnek egy bizonyos meggyốzôdése szolgál anticipatív akadályként. Ilyen például az, amikor az egyén a csoportjára vonatkozó negatív sztereotípiákat fogad el, ezzel az esetleges ku- 
darcot nem saját magával, hanem a csoporttal köti össze (Burkley és Blanton, 2008; Kim, Lee és Hong, 2012). Kim és munkatársai (2012) kutatásaiból az derül ki, hogy azok a nôk inkább fogadták el a matematikával kapcsolatos negatív nemi sztereotípiákat, akik nehéz matematikai feladatra számítottak, mint akik könnyúre.

Hirt és munkatársai (1991) szerint az önakadályozó emberek többsége a mondott akadályokat részesíti elônyben a viselkedéses akadályokkal szemben. Ezt elsôsorban két tényezó indokolja: a viselkedéses önakadály (például egy igazi sérülés) valódi veszélybe sodorja a személyt, miközben a kudarc valószínúségét is ténylegesen növeli. Ezzel szemben a mondott önakadály (például a sérülésre való hivatkozás) nem jár tényleges veszéllyel, és a kudarc valószínúségét sem növeli. Rhodewalt (1990) szerint a két megjelenési formát nem érdemes élesen elválasztani egymástól, hiszen a magas vonásszintú önakadályozók esetében a kijelentések gyakran tetté alakulnak, így a mondott és a viselkedéses önakadályok összefüggnek egymással.

Az önakadályozás formáinak bemutatását követôen a következô részben az önakadályozás hátterében megbújó motivációkat vesszük számba.

\section{AZ ÖNAKADÁLYOZÁS ALAPJÁUL SZOLGÁLÓ MOTIVÁCIÓK}

Az önakadályozás hátterében megbúvó motivációk kapcsán két fố témakört illetôen zajlik élénk tudományos vita. Az elsô kérdésrôl már részben volt szó: az önakadályozás magyarázatában kezdettôl fogva megjelennek a Kelley (1971) által leírt leszámítolás és felnagyítás elvei (pl. Jones és Berglas, 1978). A leszámítolás szerint az önakadályozás használata azért eloonyös, mert kudarc esetén az önakadály leszámítolja a cselekvô képességeinek szerepét. A felnagyítás szerint az önakadályozás használatát az indokolja, hogy a cselekvô által felállított akadály ellenére bekövetkezô siker kihangsúlyozza, felnagyítja a cselekvô képességeit. Ezt a logikát követve az önakadály lehet az önértékelés kudarcokkal szembeni védelmének eszköze, de ugyanakkor az önértékelés siker esetében történố növelésének eszköze is. Az elsố vita tehát arra vonatkozik, hogy mi az önakadályozás elsôdleges célja: az önértékelés védelme vagy az önértékelés erôsítése. A kezdeti kutatások és a legtöbb tanulmány szerint mindkét célt egyszerre tudja szolgálni (Ferrand, Tetard és Fontayne, 2006; Higgins, 1990; Jones és Berglas, 1978). $\mathrm{Az}$ is lehetséges, hogy szisztematikus kapcsolat van a vonás szintû önértékelés és az önakadályozás célja között: míg az alacsony önértékelésû egyének az önakadályozást önvédelmi, addig a magas önértékelésû egyének önértékelés növelő céllal használják (Rhodewalt, Morf, Hazlett és Fairfield, 1991; Tice, 1991).

Az empirikus vizsgálatok kevés kivételtôl eltekintve (pl. Levesque, Love és Mendenhall, 2001; Feick és Rhodewalt, 1997) nem találtak bizonyítékot az önértékelést növelő hatásra, a kutatások jelenlegi állása szerint az önakadályozás mindenekelőtt az önértékelés védelmének céljából történik (Hendrix és Hirt, 2009; Rhodewalt és Tragakis, 2002). Az önértékelést növelő hatás elmaradásának egyik oka az lehet, hogy a sikeres teljesítések révén még nagyobb elvárások nehezednének az önakadályozóra (McCrea és Hirt, 2001).

Az elsô kérdés tehát az, hogy mi az önakadályozás fố célja: az önértékelés védelme, az önértékelés erôsítése vagy mindkettô egyszerre? A második kérdés ehhez szorosan 
kapcsolódik: kinek szól az önakadályozás? Ez a vita Kolditz és Arkin 1982-ben megjelent tanulmánya alapján indult el: az önakadályozás vajon az egyén saját, személyes szelfjének szól, vagy inkább egy kifelé irányuló, én-megjelenítési stratégia? Jones és Berglas (1978) megalapozó tanulmányukban a személyes szelfet helyezték a középpontba, azonban Kolditz és Arkin (1982) azt találták, hogy a vizsgálati személyek hajlamosabbak az önakadályozó opció (teljesítménygátló gyógyszer beszedése) választására akkor, ha a vizsgálatvezetố jelen van a gyógyszer választásánál, és késôbb is nyomon követi a vizsgálati személy teljesítményét. Ezt megerôsítik azok a kutatási eredmények, melyek szerint a magasabb nyilvános éntudatossággal (public self-consciousness; Fenigstein, Scheier és Buss, 1975) rendelkezô egyének esetében (akik folyamatosan külsó, megfigyelhetô jegyekre fókuszálnak, különösen atekintetben, hogy mások hogyan értékelik azokat) magasabb az önakadályozás szintje, mint annak alacsony szintjével bíróknál (Shepperd és Arkin, 1989b). Weary és Williams (1990) azonban felhívja a figyelmet, hogy a benyomásformálás és az önkép kialakítása egymástól közel sem független folyamat egyrészt az önészlelés, másrészt a közönség reakciójának az internalizációja nyomán. Rhodewalt és Tragakis (2002) szintén ezt a nézetet hangsúlyozza, és az önakadályozás elsôszámú célpontját a személyes szelfre helyezi. Mello-Goldner és Wurf (1997) empririkus vizsgálatukban érdekes nemi különbséget találtak: a nôk inkább a privát helyzetekben, míg a férfiak inkább a nyilvános helyzetekben önakadályoznak. Ez az eredmény arra utalhat, hogy a férfiak és a nók esetében eltérô az önakadályozás „közönsége”.

A tanulmány következô részében az önakadályozást előidézó és gátló tényezôket mutatjuk be.

\section{AZ ÖNAKADÁLYOZÁST BEFOLYÁSOLÓ TÉNYEZŌK}

Az önakadályozást befolyásoló tényezôket illetően kétféle forrást lehet elkülöníteni: elôfordulása egyrészt a szituációtól, kontextustól, másrészt a személy tulajdonságaitól függ. Az önakadályozást befolyásoló kontextuális jellemzók közül talán legfontosabbak a végrehajtandó feladat jellemzôi. Az önakadályozás megjelenését leginkább az olyan feladattípusok hívják, amelyek az egyén számára fontosak, relevánsak (Pyszczynski és Greenerg, 1983), fenyegetôek (Finez, Berjot, Rosnet és Cleveland, 2011; Shepperdés Arkin, 1989a), valamint az egyéni képességek szempontjából diagnosztikusak (Shepperdés Arkin, 1989b). Ez azért van így, mert az ilyen jellegú feladatokban kockáztatja az egyén leginkább a képességei megítélését.

Egy másik feladathoz köthetô jellemzô az, hogy a feladatot nyilvánosan, közönség jelenlétében kell-e végrehajtani vagy annak hiányában. Az önakadályozás általánosan véve gyakoribb a nyilvános helyzetekben (Hirt, McCrea és Kimble, 2000; Kolditz és Arkin, 1982). Ennek magyarázata az egyén által kialakítani vágyott kedvezô képben rejlik, amivel magát kompetensnek kívánja láttatni. Léteznek olyan empirikus eredmények, amelyek szerint nem csupán a közönség jelenléte vagy hiánya, hanem a közönség összetétele is befolyásolja az önakadályozás megjelenését. Brown és Kimble (2009) azt találták, hogy az önakadályozás mértéke magasabb ellenkezô nemú kísérletvezetô jelenlétében. Ez a hatás kifejezetten erôs volt nôii kísérletvezetô és férfi vizsgálati személy esetében. 
Az önakadályozás megjelenése és a feladat kapcsolatában fontos az is, hogy a feladattal kapcsolatban milyen célokat hangsúlyoz a környezet. Dweck (1986) célorientációs elméletében megkülönböztet elsajátítási és viszonyító célokat. Az elsajátítási célok arra vonatkoznak, hogy egy adott feladathelyzetben új készségeket, képességeket sajátítson el a cselekvô, míg a viszonyító célok a másik túlteljesítésére, az egyéni képességek kifejezésére vonatkoznak (Fejes, 2011). A célstruktúrák elmélete (Ames, 1992) a környezet bizonyos célorientációt hangsúlyozó jellegére utal. A célorientációs és a célstruktúrák elméletete, valamint az önakadályozást összekötô kutatások eredményei szerint, ha a környezet (például egy iskolai helyzet) az elsajátítási célokat hangsúlyozza, az kevesebb önakadályozáshoz vezet, míg ha a viszonyító célokat, az növeli az önakadályozás megjelenését (Midgley és Urdan, 2001; Standage, Treasure, Hooper és Kuczka, 2007; Urdan, Midgley és Andreman, 1998).

A feladathelyzetben a cselekvô csoporttagsága és a ténylegesen jelen lévô társak is befolyásolhatják az önakadályozás megjelenését. Stone (2002) vizsgálatában például fehér boorú sportolók, ha észlelték a fehér csoporttal kapcsolatos negatív sztereotípiákat (a fehérbőrúek kevésbé sportosak) kevesebbet gyakoroltak a közelgô feladatra, mint a kontroll csoport tagjai, akik nem voltak ennek a fenyegetô információnak kitéve. A jelenséget feltehetôen az magyarázza, hogy az akadályok felállításával el tudták kerülni azt a helyzetet, amely megerôsítheti a fennálló sztereotípiát (azért teljesítettek rosszul, mert keveset gyakoroltak vs. azért teljesítettek rosszul, mert fehérbôrüek). A csoporttagok más, közvetlenebb módon is befolyásolják az önakadályozás megjelenését. Az olyan csoportok tagjai, akik a csoportjukat összetartónak tartják (magas csoportkohézió), nagyobb valószínúséggel számolnak be hátráltató tényezôkrôl, mint az alacsony csoportkohézióval rendelkezó csoportok tagjai (Carron, Prapavessis és Grove, 1994; Hausenblas és Carron, 1996). Carron és munkatársai (1994) ezt azzal magyarázzák, hogy a magasra értékelt, összetartó csoportokban csalódást okozni a csapattársaknak fenyegetôbb, mint a kevésbé összetartó csoportokban. A társakat illetốen az önakadályozás megjelenésének valószínúségét növelô tényezô még a társas kirekesztés előrevetítése. Azok a vizsgálati személyek, akik egy álszemélyiségteszt alapján olyan visszajelzést kaptak, hogy végül nem találnak társra, többet halogattak a rákövetkezố feladathelyzet előtt, mint a kontrollcsoport, akik nem kaptak ilyen visszajelzést (Twenge, Catanese és Baumeister, 2002). Szintén előre jelzi az iskolai önakadályozásban való részvételt a negatív iskolai orientációval rendelkezô barátok jelenléte (Midgley és Urdan, 1995).

A szituatív okok közé sorolható a hangulat önakadályozásra tett hatása. Alter és Forgas (2007) eredményei szerint a boldog, vagyis pozitív hangulat szignifikánsan növeli az önakadályozásra való hajlandóságot. Ez kifejezetten igaz volt azokban a helyzetekben, amikor a pozitív hangulat olyan hamis visszajelzésekkel társult, amelyek függetlenek voltak a vizsgálati személy valódi teljesítményétôl. A szerzốk eredményeiket azzal magyarázzák, hogy amennyiben a visszacsatolt információ nem megbízható/informatív, az emberek a pozitív hangulatukat igyekeznek fenntartani, ezért az önakadályozás segítségével felmentik magukat az esetleges kudarc következményei alól. További, önakadályozást erôsítô szituációs faktor a szelf mások helyett önmagára való fókusza (objective self-awareness; Hirt, McCrea és Kimble, 2000; Kimble és Hirt, 2005). A detektív tükrön keresztül/kamerával megfigyelt kísérleti személyek (akik tudták, hogy 
megfigyelik ôket, miközben a személyiségükre vonatkozó kérdéssort töltöttek ki) szignifikánsan kevesebbet gyakoroltak egy feladathelyzet elốtt, mint azok a társaik, akiknek egy fiktív személyt kellett jellemezniük egy leírás alapján detektív tükör és kamera jelenléte nélkül.

A kísérleti elrendezés további jellemzői is befolyásolhatják az önakadályozás megjelenését. McCrea és Flamm (2012; McCrea, 2008) nyelvi primingot használtak vizsgálatukban. A feladat végrehajtást megelőzô nyelvi előfeszítés, az előfeszítés típusától függốen, több illetve kevesebb önakadályozáshoz vezetett a kísérleti csoportokban szemben a kontroll csoportokkal. Az olyan típusú nyelvi priming, mint a „ha ...-t csinálok, rosszabbul fogok teljesíteni a feladatban”, vagy „ha többet tanultam volna, ötöst kaphattam volna" ahhoz vezetett, hogy a vizsgálati csoport tagjai kevesebbet gyakoroltak a teljesítményhelyzetben, mint a kontroll csoport tagjai. A „ha ...-t csinálok, jobban fogok teljesíteni a feladatban”, illetve a „ha..., akkor” formulával megfogalmazott célok éppen ellentétes hatáshoz vezettek, azaz az önakadályozás ritkább volt az elôfeszített csoportban, mint a kontroll csoportban (McCrea, 2008; McCrea és Flamm, 2012; Thürmer, McCrea és Gollwitzer, 2013).

A szituatív tényezók és az önakadályozás kapcsolatában természetesen nemcsak az önakadályozást elóidézô környezeti feltételek érdekesek, hanem az önakadályozást csökkentô, a valódi potenciál kibontakozását támogató szituatív tényezôk is. Fentebb már beszámoltunk három ilyenrôl: az elsajátítási célok környezet általi hangsúlyozása (célstruktúra), a „ha ...-t csinálok, jobban fogok teljesíteni a feladatban” típusú nyelvi priming, illetve a „ha..., akkor” formulával megfogalmazott célok. Ezek az eredmények azért is különösen fontosak, mert megmutatják, hogy az eltéró instrukció és a külsố elvárások különbségei befolyásolják a valódi képességek és az elért teljesítmények kapcsolatát. Az önakadályozást csökkentô egyéb szituatív tényezôk közé tartoznak a magas külsố jutalmak (például pénz), mert ezek jelenlétében a mondott akadályok még a fontos feladatok esetében sem jelennek meg (Greenberg, Pyszczynski és Paisley, 1984). Továbbá Shepperd és Arkin (1989a) eredményei szerint önakadályozás csak akkor jelenik meg, ha nem volt elôzetesen fennálló akadály, hiszen ez esetben szükségtelen további kockázatokat vállalna az egyén.

Szintén fontos azt megjegyezni, hogy ha lehetôséget adunk az egyénnek, hogy pozitívan megerôsítse magát a teljesítményhelyzet előtt (például a legfontosabb erényeikrôl írhatnak esszét), az szintén az önakadályozási tendencia csökkenéséhez vezet (Finez és Sherman, 2012; Kimble, Kimble és Croy, 1998; Siegel, Scillitoe és Parks-Yancy, 2005). Az önmegerôsítés azonban csak akkor múködik, ha a megerôsítés nem a szóban forgó feladatot idézi (például iskolai feladat nem iskolai eredményességrôl szóló esszével párosítva), hiszen az McCrea és Hirt (2011) szerint az csak tovább növelné a tétet, vagyis a feladat egófenyegetô jellegét.

Az mindenképpen látható, hogy több olyan szituatív tényezó van, ami összefügg az önakadályozás megjelenésével. A kutatások ugyanakkor arra is rámutatnak, hogy vannak az önakadályozásnak olyan a kontextustól független befolyásoló tényezôi is, amelyek a személy stabilabb vonásaihoz, tulajdonságaihoz kötôdnek. Ezek között is megkülönböztethetünk előidéző és gátló tényezôket.

Ahogy arról már volt szó, az önértékelés és az önakadályozás komplex kapcsolatban állnak egymással. A kezdeti kutatásokban amellett érveltek, hogy azok vesznek 
részt önakadályozásban, akiknek az önértékelése bizonytalan, függetlenül attól, hogy magas vagy alacsony-e (Harris és Snyder, 1986; Newman és Wadas, 1997). A késôbbi kutatások inkább arra fókuszáltak, hogy a magas vagy alacsony önértékelés jár-e együtt több önakadályozó viselkedéssel? Néhány szerzô amellett érvelt, hogy a magas önértékelésû egyének hajlanak az önakadályozásra inkább, hiszen neki több forog kockán, van mit megvédeniük (pl. Rhodewalt, 1990; Rhodewalt és Tragakis, 2002; Tice és Baumeister, 1990). Az empirikus eredmények túlnyomó többsége viszont arra mutat, hogy az alacsony önértékelésú emberekre inkább jellemzố az önakadályozás. Ennek fố okai, hogy az alacsony önértékelésú emberek több olyan helyzettel találkoznak, ahol a végkifejlet bizonytalan, valamint a társas értékelés is fenyegetôbb a számukra (Coudevylle, Gernigon és Martin Ginis, 2011; Martin és Brawley, 2002; Prapavessis és Grove, 1998; Richards, Johnson, Collins és Wood, 2002). Az ellentmondásos empirikus eredmények részben abból is fakadhatnak, hogy a két csoport (magas vs. alacsony önértékelésû) különbözô céllal használhat önakadályozási formákat. Eszerint a megközelítés szerint a két csoport között nem az önakadályozás használatának gyakoriságában van a különbség, hanem az önakadályozás használatának okában (Kim, Chiu és Zou 2010; Rhodewalt és mtsai, 1991; Tice, 1991). Bonyolítja a helyzetet, hogy az önértékelés kutatásában megkülönböztetnek explicit és implicit önértékelést. Lupien, Seery és Almonte (2010) eredményei szerint az önakadályozásra leginkább azok a személyek hajlamosak, akik magas explicit, viszont alacsony implicit önértékeléssel rendelkeznek.

Egy másik személyhez köthetô befolyásoló tényezô a személy implicit elmélete arról, hogy a saját képességei mennyire megváltoztathatóak vs. veleszületettek. Az inkrementális implicit személyiségelmélettel rendelkezô személyek úgy vélik, hogy a képességeik változtathatóak, javíthatóak. Ezzel szemben a rögzített implicit személyiségelmélettel rendelkezô személyek úgy gondolják, hogy a képességeik megváltoztathatatlanok, veleszületettek. Az empirikus vizsgálatok azt mutatják, hogy a rögzített implicit személyiségelméletekkel rendelkezó személyek nagyobb eséllyel vesznek részt önakadályozásban, mint az inkrementális elméletekkel rendelkezó személyek (Ommundsen, 2001; Snyder, Malin, Dent és Linnenbrink-Garcia, 2014). Aki a képességeit veleszületettnek és megváltoztathatatlannak ítéli, fenyegtôbbnek éli meg a kudarcokat is, amik szintén végletesebbnek túnnek. Ezzel összefügg az is, hogy egy adott teljesítményhelyzetben az egyén milyen célokkal fog rendelkezni: inkább elsajátítási célokat fogalmaz meg (új képességek, készségek megszerzése, a meglévô képességek, készségek javítása) vagy viszonyító célokat (felülmúlni és/vagy nem alulmúlni másokat). A viszonyító célokkal rendelkezô személyek nagyobb valószínúséggel folyamodnak önakadályozáshoz. Ez azzal magyarázható, hogy az egyének másokkal összehasonlítva és másokhoz képest kompetensebbnek kívánják látni és láttatni magukat, és „folt nélkül” kikerülni a társas összehasonlító helyzetbôl (Midgley és Urdan, 2001; Standage és mtsai, 2007; Urdan, Midgley és Andreman, 1998). Ez a kép némileg árnyalódott azzal, hogy a célorientációkhoz és a célstruktúrákhoz közelítô és elkerülố irányt rendeltek a sikerorientáció és kudarckerülés elméleti kereteit beépítve (Elliot és Church, 1997; Elliot és McGregor, 2001). Ezzel a viszonyító céloknak az alábbi két fajtája jött létre: teljesítménykeresô (mások túlteljesítésére fókuszál) és teljesítménykerülô (másoknál alacsonyabb teljesítmény elkerülésére fókuszál) viszonyító cél. Az elsajátítási célok szintén két csoportra bomlottak: teljesítménykeresô (a teljes elsajátításra, megértésre fókuszál) és teljesít- 
ménykerülő (a hiányos elsajátítás, megértés elkerülésére fókuszál) elsajátítási célokra. Úgy tûnik, hogy mind a viszonyító, mind az elsajátítási célok teljesítménykerüló irányultsága önakadályozáshoz vezet (Chen, Wu, Kee, Lin és Shui, 2009; Midgley és Urdan, 2001; Ommundsen, 2004; Urdan, 2004).

Figyelemreméltó eredményt kapott Uysal és Knee (2012), akik az önkontroll és az önakadályozás kapcsolatát vizsgálták: a vonásként meghatározott önkontroll alacsony szintje megbízhatóan eloore jelzi az önakadályozás minden formáját önértékeléstôl, önbizalomhiánytól, nemtôl és társas kívánatosságtól függetlenül. A szerzôk értelmezése szerint elképzelhetô, hogy az alacsony önkontroll következtében megjelenô viselkedésformák tanulás révén rögzülnek. A szerzók példájában egy alacsony önkontrollal rendelkezô diákot mutatnak be, aki sok idôt tölt internezéssel. Idôvel rájön, hogy ez jó magyarázatul szolgál a gyenge iskolai teljesítményére, így folytatja ezt a tevékenységet (internetezés), és egyúttal utólagos attribúciós elônyöket kovácsol belóle („azért lett rossz a vizsgám, mert túl sokat interneteztem, ennek nincs köze a képességeimhez”). Néhány alkalom után ez rögzülhet, és akár stratégikusan is használható. A szerzook másik magyarázata szerint az önakadályozás az önszabályozásban bekövetkezô kudarcként is felfogható. Az alacsony önkontrollal jellemezhetô egyének nagyobb valószínûséggel vallanak kudarcot az önszabályozásban, és az azonnali kielégülést részesítik elônyben a hosszú távú költségekért cserébe.

Az önakadályozás szorosan kapcsolódik az oktulajdonítás szokásos módjaihoz, az úgynevezett attribúciós mintázatokhoz. A magas oksági bizonytalansággal jellemezhetô egyének több teljesítményhelyzet elốtti akadályról számolnak be, mint azok, akik alacsony oksági bizonytalansággal rendelkeznek (Thompson és Hepburn, 2003). Az attribúciós mintázatok tanulmányozása azt mutatja, hogy az önakadályozásra hajlamos egyének függetlenül az esemény kimenetelétôl (pozitív vagy negatív) külsô és nem stabil attribúciókat gyártanak (Murray és Warden, 1992; Rhodewalt, 1990), ezzel is távol maradva a képességekre (mint klasszikusan belsô és stabil) vonatkozó oktulajdonítástól. Így az eseményeket kontrollálhatatlannak és előrejelezhetetlennek tartják (Arkin és Oleson, 1998). Ez az eredmény egybecseng azzal, hogy az önakadályozásnak inkább önértékelést védô, mint növelő hatásairól számolnak be a kutatások (lásd feljebb).

Növeli az önakadályozás elôfordulási gyakoriságát a külsố vagy másoktól származó célok felé való orientáltság (Midgley és Urdan, 1995). A szerzók szerint ez amiatt van, hogy az önakadályozók külsố teljesítménykritériumok alapján határozzák meg a kompetenciáikat, ami nem a szelf belsô, stabil része. Az önakadályozás és a maladaptív perfekcionizmus közötti pozitív kapcsolat is ide kapcsolódik (Ferrari, 1992; Flett és mtsai, 1992; Mushquash és Sherry, 2012; Stewart és De George-Walker, 2014). Flett és Hewitt perfekcionizmus fogalmában a maladaptív forma legfontosabb alfaktorát képezi a szociálisan elôírt perfekcionizmus, ami a mások által támasztott tökéletesség elvárásokra vonatkozik. A negatív perfekcionizmusra jellemzô elérhetetlenül magas célok kitûzése szükségképpen magában rejti a kudarcot, ezért logikusnak tûnik az önakadályozással történố védekezés (Török és Szabó, 2015).

A személy vonásain, képességein, implicit teóriáin és attribúciós tendenciáin túl a neme is erôsen befolyásolja az önakadályozás megjelenését. A mondott akadályok tekintetében a férfiak és nôk többnyire hasonló mennyiségú gátló tényezôrôl számolnak be (Arkin és Oleson, 1998; de kivétel pl. Hirt, Deppe és Gordon, 1991), azon- 
ban a viselkedéses önakadályozás kevés kivételtôl eltekintve (pl. Ferrari és Tice, 2000) csak férfiakra jellemzô (Berglas és Jones, 1978; Hirt és mtsai, 2000; McCrea, Hirt és Milner, 2008; Rhodewalt és Davison, 1986). Az utóbbi különbség magyarázatára több lehetséges teória is született. A kezdeti magyarázatok abban keresték a megoldást, hogy a nôket a nyilvános helyzetben való (vágyott) képességdemonstrálás visszariasztja (Rhodewalt, 1990), azonban Hirt és munkatársai (2000) empirikus vizsgálatukban ezt nem támasztották alá. Egy másik magyarázat abból indult ki, hogy a férfiak magasabb önértékeléssel rendelkeznek, mint a nôk (Kling, Hyde, Showers és Buswell, 1999), vagyis ók többet veszíthetnek egy vesztes szituációban. Ezt a felvetést szintén megcáfolni látszanak az empirikus eredmények (pl. McCrea és Hirt, 2001), ugyanis az önértékelés kontrollálása nem tünteti el a különbséget a két nem között. Felmerült szintén magyarázatként, hogy a sztereotipikusan férfias iskolai környezetben a teljesítmény fontosabb a férfiaknak, mint a nôknek, azonban a sztereotipikusan nóies területeken (mint pl. szociális interakciók) szintén a férfiak önakadályoztak többet viselkedéses formában a nókhöz viszonyítva (Kimble, Funk és DaPolito, 1990). Egy újabban felmerült magyarázat lehetôsége abból az eredménybôl indult ki, miszerint a nôk által vallott kudarcokat az emberek nagyobb valószínúséggel titulálják képességbeli hiányosságnak, míg a férfiak által vallott kudarcokat ehelyett erófeszítésbeli hiányosságnak (Swim és Sanna, 1996). Logikusnak tûnt tehát az a felvetés, hogy a férfiak több attribúciós elônyt élveznek a viselkedéses önakadályozás kapcsán, hiszen a nôk kudarcaiból a megfigyelôk képességbeli hiányosságokra következtetnek. A jelenleg fennálló, és legmeggyôzôbb magyarázat azokból a kutatásokból indult ki, miszerint a viselkedéses formán önakadályozó személy neme nem befolyásolja megítélését (legyen akár férfi, akár nô, aki nem készül a vizsgára), azonban az önakadályozót megfigyelố személy neme igen. A nôk sokkal kritikusabbak voltak az önakadályozókként leírt személyekkel szemben, mint a férfiak (Hirt, McCrea és Boris, 2003; Milner, 2009). A további kutatási eredmények ezt vizsgálva azt találták, hogy a viselkedéses önakadályozásban megfigyelhetô nemi különbség magyarázata az, hogy a nôk többre értékelik (személyes és normatív értelemben egyaránt) az erôfeszítést, elfogadhatatlanabbnak tartják annak hiányát, mint a férfiak (McCrea és mtsai, 2008a; McCrea, Hirt, Hendrix, Milner és Steele, 2008).

További, a személyhez köthetố hajlamosító faktor lehet még az imposztor jelenség is (Ferrari és Thompson, 2006; Want és Kleitman, 2006). Imposztor jelenség alatt azt értjük, amikor a siker objektív bizonyítéka ellenére az egyén úgy érzi, hogy valójában kevesebbre képes, a környezete ôt túlértékeli, ennélfogva pedig egy csaló. Minthogy az imposztorok jellemzôen tartanak a negatív értékeléstől, szociális elfogadásra és elismerésre törekszenek, fokozott énbemutatás jellemzi óket annak érdekében, hogy elkerüljék a negatív értékelést (Ferrari és Thompson, 2006).

Minthogy az önakadályozók a napi események szintjén is túlnyomórészt külsô, instabil attribúciókat gyártanak (lásd feljebb), nem meglepô, hogy a külsố kontroll is kapcsolatban áll az önakadályozással. Stewart és De George-Walker (2014) kutatási eredményei alapján a külsô kontroll elôrejelzi azönakadályozás megjelenését.

Minthogy az önakadályozás alapvetôen elkerülő motivációs bázisú (lásd feljebb), szintén elôre jelzi a megjelenését az alacsony sikerorientáció és magas kudarctól való félelem (De Castella, Byrne és Covington, 2013). 
A személyiség szintjén a szituációhoz hasonlóan szintén azonosíthatók preventív faktorok. Ezek többségében a gátló tényezók ellentétjei: a biztos önértékelés, az inkrementális implicit személyiségelméletek vallása, az elsajátítási célok hangsúlyozása a viszonyító célokkal szemben, az önkontroll magas szintje, az alacsony oksági bizonytalanság, a belsố kontroll és a magas énhatékonyság. Knee és Zuckerman (1998) vizsgálata szerint ezek mellett még fontos a magas autonómia és az alacsony észlelt kontroll is, hiszen a magas autonómiával jellemezhetô egyének kevesebb önakadályozást használnak, mint az alacsony autonómiával rendelkezók.

Az 1. táblázatban bemutatjuk az önakadályozást befolyásoló szituatív és személyiség tényezóket. A tanulmány következó részében az önakadályozás következményeit veszszük számba.

1. táblázat. Az önakadályozást befolyásoló faktorok

\begin{tabular}{|c|c|c|}
\hline & Szituatív & Személyhez kapcsolódó \\
\hline $\begin{array}{c}\text { Önakadályozást } \\
\text { előidézô }\end{array}$ & $\begin{array}{l}\text { - Fontos, ego-fenyegetố feladat } \\
\text { - Nyilvános helyzet, közönség } \\
\text { jelenléte (ellenkezô nemú kísér- } \\
\text { letvezetô) } \\
\text { - Eredmény/viszonyító célokat } \\
\text { hangsúlyozó környezet } \\
\text {-Negatív sztereotípia-fenyegettség } \\
\text {-Erôs észlelt csoport kohézió } \\
\text {-Társas kirekesztés elôrevetítése } \\
\text {-Negatív iskolai orientációval ren- } \\
\text { delkezó barátok jelenléte } \\
\text {-Boldog hangulat } \\
\text {-Szelf önmagára fókuszálását erő- } \\
\text { sítố környezet (tükör, kamera) } \\
\text { - Nyelvi priming }\end{array}$ & $\begin{array}{l}\text { - Alacsony önértékelés } \\
\text { - Hamis önértékelés } \\
\text { - Rögzített implicit személyiségel- } \\
\text { mélet } \\
\text { - Eredmény/viszonyító } \\
\text { célorientáció (kifejezetten } \\
\text { teljesítménykerüló irányultsága) } \\
\text { - Alacsony önkontroll } \\
\text { - Magas oksági bizonytalanság } \\
\text { - Másoktól származó célok felé } \\
\text { való orientáltság } \\
\text { - Maladaptív perfekcionizmus } \\
\text { - Férfinek lenni (nem) } \\
\text {-Magas éntudatosság } \\
\text {-Imposztor jelenség } \\
\text {-Külsố kontroll } \\
\text { - Alacsony sikerorientáció és ma- } \\
\text { gas kudarctól való félelem }\end{array}$ \\
\hline $\begin{array}{c}\text { Önakadályozást } \\
\text { gátló }\end{array}$ & $\begin{array}{l}\text { - Elsajátítá célokat hangsúlyozó } \\
\text { környezet } \\
\text { - Nyelvi priming } \\
\text { - Magas külsố incentív } \\
\text { - Egy elôzetesen fennálló akadály } \\
\text { jelenléte } \\
\text { - Nem a szóban forgó területen } \\
\text { való önmegerôsítés } \\
\text { - Feltétlen elfogadás } \\
\text { - Kognitív leterheltség }\end{array}$ & $\begin{array}{l}\text { - Tanulási/elsajátítási } \\
\text { célorientáció (kifejezetten } \\
\text { teljesítménykeresó́ irányultsága) } \\
\text { - Magas autonómia }\end{array}$ \\
\hline
\end{tabular}




\section{AZ ÖNAKADÁLYOZÁS KÖVETKEZMÉNYEI}

További lényeges kérdés az önakadályozással kapcsolatban, hogy annak milyen elônyös és hátrányos következményei vannak egyrészt az önakadályozó személyre és fơleg a teljesítményére, másrészt az önakadályozó személy megítélésére (Milner, 2009; Schwinger, Wirthwein, Lemmer és Steinmayr, 2014).

Ahogy arról már beszámoltunk, számos tanulmány szerint a kudarc elootti önakadályozás megvédi az önértékelést, mert az egyén nem a képességeit tekinti a kudarc okának (Berglas és Jones, 1978). Az önakadályozás lényege éppen ez: az egyén segítségével továbbra is a képességeinek a potenciáljára tud támaszkodni ahelyett, hogy az aktuális teljesítményét nézné. Ez különösen kedvezô kudarc esetén, hiszen így a negatív kimenetel ellenére is fenn tudja tartani azt az illúziót, hogy a képességei valójában magasak. Rhodewalt (1990) kiemeli, hogy mind objektív méréssel, mind önbevallás alapján kimutatható ez az eredmény. Kiemelhető még az önakadályozás szorongást szabályozó hatása is (vö. az „esélytelenek nyugalma”). Snyder és Higgins (1988) vizsgálatukban azt találták, hogy az önakadályozás csökkenti az önértékelési aggodalmakat, így segít a feladatra koncentrálásban és a magasabb szintú teljesítésben is. Coudevylle, Martin Ginis, Famose and Gernigon (2008) kutatási eredményei szerint azok a sportolók, akik erôsebb hajlammal rendelkeznek az önakadályozás használatának irányába, feladathelyzet elốtt kognitív szorongásukat nagyobb mértékben ítélik facilitálónak, amennyiben lehetôségük van önakadályozásra. Más kutatók eredményei szerint azok az önakadályozásra hajlamos egyének, akik teljesítményhelyzet elôtt önakadályoznak (nem gyakorolnak), jobban bevonódnak és jobban élvezik az azt követô feladatot, mint akik nem, ugyanakkor az erre nem hajlamos egyénekre ugyanez akkor jellemzô, amikor többet gyakorolnak (Deppe és Harackiewicz, 1996). Ráadásul azok, akik önakadályozást használnak, kisebb valószínúséggel mutatnak csökkenést a pozitív érzéseik szintjét illetôen, mint akik nem önakadályoznak (Drexler, Ahrens és Haaga, 1995), és erôsebb kontrollt is éreznek (Thompson, 2004).

Az önakadályozás fentebb felsorolt pár elônyös következménye ellenére, a kutatók többsége a negatív következményeket hangsúlyozza. Zuckerman, Kieffer és Knee(1998) longitudinális kutatásukban azt találták, hogy a magas önakadályozási hajlammal rendelkezôk (a kevésbé önakadályozásra hajlamosakhoz képest) nagyobb mértékben alkalmaznak elégtelen coping stratégiákat, rosszabbul alkalmazkodnak, ez pedig további önakadályozáshoz vezet, ördögi kört kialakítva. Zuckerman és munkatársai (2005) longitudinális vizsgálata szerint az önakadályozás használata negatív hatással van a szubjektív jóllétre és az egészségre. Idôvel ráadásul az önakadályozók többször választanak elkerüló megküzdési stratégiákat (pl. tagadás), és önmaguk ellen fordulnak (pl. önhibáztatással), illetve elfordulnak a „nehéz” realitástól, és egy olyan valóságot konstruálnak maguknak, ami jobban támogatja az énképüket. Az önakadályozó egyénnek aztán csökken a kompetenciáival való elégedettsége, ami mediálja az önakadályozás és a negatív hangulat közötti kapcsolatot. A negatív hangulat az önakadályozás mértékével ugyancsak növekszik, míg a szubjektív vitalitás csökken. Zuckerman és munkatársai (2005) vizsgálatában idôvel ráadásul növekszik az anyaghasználat mennyisége és annak köre is, miközben az önakadályozók munkájukban az intrinzik motiváció csökkenését élik meg. Emellett egy további maladaptív körforgás 
is elindul: az önakadályozás idôvel az önértékelés csökkenéséhez vezet, ami viszont tovább növeli az önakadályozás mértékét, így a kettô kölcsönösen és folyamatosan megerôsíti egymást. Bailis (2001) sportolókkal végzett vizsgálatából az derül ki, hogy az önakadályozás negatív viselkedésbeli változásokhoz vezet, például a táplálkozás és az edzés minôségében. Az önakadályozásnak az önakadályozó személyre vonatkozó negatív következményeképpen tehát a szubjektív jóllét és az egészség romlása, a rossz megküzdési stratégiák választása, a realitástól való elfordulás, viselkedésbeli változások (anyaghasználat, rossz táplálkozás, kevesebb edzés) és a belsô motiváció csökkenése jelenik meg.

A teljesítmény kapcsán az eredmények kettôsek. Az önakadályozás ugyan tartalmaz pozitív aspektusokat is (lásd pl. fentebb a szorongásszabályozás és a koncentráció, magasabb feladatmegoldási színvonal közötti kapcsolatot, vagy Ryska, 2002; Rhodewalt és Davison, 1986; Bailis, 2001) a legtöbb kutatás szerint mégis a viselkedéses, illetve a krónikusan megjelenő önakadályozás kifejezetten negatívan hat a teljesítményre (pl. Rhodewalt, 1990; Thompson, 2004; Urdan, 2004; Schwinger és mtsai, 2014). A további kutatásokban fontos lenne azonban megkülönböztetni a viselkedéses önakadályozás, a mondott akadályok és az önakadályozási hajlam egymástól független teljesítménybefolyásoló hatásait, illetve az azonnali és a hosszú távú következményeket.

Az önakadályozással kapcsolatban felvethetô fontos következmény továbbá az önakadályozó személy külsô megítélése. Az önakadályozás egyik felfogása szerint az önakadályozás a szelf-prezentáció egyik eszköze (Kolditz és Arkin, 1982; Prapavessis, Grove és Eklund, 2004), így érdemes vizsgálni, hogy milyen hatással van az észlelôre. A kutatások többsége arra jutott, hogy miközben az önakadályozás bizonyos értelemben eléri a hatását (az észlelô fél kevésbé köti össze a kudarcot a cselekvô képességeivel, ha akadályokat tapasztal), mégis az önakadályozószemély negatív megítéléséhez vezet. A vizsgálati személyek az objektíve egyenlô teljesítményt negatívabbnak ítélték, amennyiben az önakadályozótól származott, mintha nem (Rhodewalt, Sanbonmatsu, Tschanz, Feick és Waller, 1995). Továbbá az önakadályozó személy motiválatlannak, bizonytalannak, kevésbé felelôsségteljesnek tûnik (Levesque és mtsai, 2001; Luginbuhl és Palmer, 1991), mint az, akire nem jellemzó az önakadályozás. A nemek tekintetében azt találták, hogy a önakadályozó személye nem befolyásolja a mások általi megítélését, viszont a nốk kevésbé kedvelik az önakadályozást alkalmazó egyéneket, és gyanakvóbbak a motivációikat illetôen is (Hirt, McCrea és Boris, 2003; Milner, 2009). Levesque és munkatársai (2001), valamint Milner (2009) vizsgálata ugyanakkor azt mutatja, hogy az önakadályozó személyeket a megfigyelők szociálisabbnak jellemezték, mint a nem önakadályozó társaikat. Milner (2009) szerint ez azzal magyarázható, hogy az önakadályozó személy kevesebb teljesítményhez kötôdô tevékenységben vesz részt, miközben több szociálisban (pl. több idôt tölt másokkal). Az önakadályozás következtében a megfigyelókben kialakuló felmentés - a teljesítmény és a képesség elválasztása - korlátozottabb mértékben múködik a dolgozó felnôtt egyéneknél, mint a diákoknál (Park és Brown, 2014). Az emberek kedvezóbben ítélik meg a mondott akadályokat, mint a viselkedéses önakadályozást (Cox és Giuliano, 1999). Siegel és Brockner (2005) érdekes eredményt kaptak: amikor egy cég ügyvezetó igazgatója használ mondott akadályokat, akkor a megítélés nem csupán ót érinti, hanem a teljes szervezetet is. A vezetô által alkalmazott mondott akadályok a szervezet negatív megítélésé- 
hez vezetnek. Crocker és Park (2004) szerint az empirikus vizsgálatokban kirajzolódó mintázat alapján leginkább az mondható el, hogy az önakadályozás rövid távú elônyei - a kudarc elválasztása a képességektôl - hosszú távú hátrányokkal kombinálódnak.

Tanulmányunk következô részében az önakadályozás mérésérôl írunk, majd ezt követốen a tanulmányt záró összefoglalóban értékeljük az eddig elvégzett teoretikus és empirikus munkát, kitérünk a gyakorlati alkalmazás lehetôségeire, és szót ejtünk a magyar vonatkozású kutatásokról is.

\section{AZ ÖNAKADÁLYOZÁS MÉRÉSE}

Az önakadályozás mérésében a legelterjedtebb eszköz a Jones és Rhodewalt által 1982-ben létrehozott Önakadályozás Skála (Self-Handicapping Scale, SHS). Az SHS az önakadályozás vonásszintú megragadására képes. Az eredeti szándék szerint az önakadályok használatának két csoportját -mondott és viselkedéses önakadályok - mérte volna (Rhodewalt, 1990), de a viselkedéses faktor gyenge megbízhatósága miatt a legtöbb tanulmány a skálát egy dimenziós eszközként használja (Greaven, Santor, Thompson és Zuroff, 2000; Hendrix és Hirt, 2009; Pulford, Johnson és Awaida, 2005). Az eredeti skála 25 itemból áll. A kérdőív elsôként rövidített változata 14 itemre csökkent (Rhodewalt, 1990), illetve Strube (1986) SHS újraelemzése az eredeti kérdôív egy megbízhatóbb, 10 állításra rövidített változatát javasolja. Az SHS-t több nyelvre adaptálták, például lengyelre (Doliński és Szmajke, 1994), törökre (Akin, 2012) és franciára (Kraïem és Bertsch, 2011). A skálát nyelven először Török, Szabó és BodaUjlaky (2015) használták. A kérdőív megfelelő statisztikai mutatókkal rendelkezik, és több tanulmányban bizonyították konstruktum és prediktív érvényességét (Rhodewalt, 1990). Az SHS-sel kapcsolatban megfogalmazott leggyakoribb kritikák a következók: nem minden esetben különíti el egyértelmúen az önakadályozást az utólagos attribúciós folyamatoktól (például kifogáskeresés), és inkább egy differenciálatlan védekezô viselkedést mér, mint specifikusan az önakadályozási hajlamot (Schwinger és mtsai, 2014).

Az önakadályozás elméleti irodalmában már korábban bemutatott hangsúlyváltás - az általános, vonásjellegú megközelítés felváltása a területspecifikus önakadályozás gondolatával - hívta életre azt az igényt, hogy az önakadályozás mérése lehetséges legyen egy adott, specifikus területre vonatkozóan. Így született meg az Iskolai Önakadályozási Skála (Urdan és Midgley, 2001), a sportspecifikus SHS (Martin és Brawley, 1999), valamint a mozgásspecifikus skála (Maddison és Prapavessis, 2007).

Az önbevallásos kérdôíves módszer egyik legfőbb korlátja az a feltevés, hogy az önakadályozó tudatosan képes reflektálni az általa használt önakadályozási módra és motivációra (ezt ma már többen kétségbe vonják: McCrea, 2008; McCrea és Flamm, 2012; McCrea és mtsai, 2009; Spalding és Hardin, 1999; Thürmer és mtsai, 2013; Twenge és mtsai, 2002). A valóság ezzel szemben feltehetốen az, hogy a kérdôívek nem képesek detektálni a diszkrét, szelektív vagy önbecsapás alapon múködô önakadályozókat (Rhodewalt, 1990). Ez a felismerés elôtérbe hozott egyéb módszereket, mind például a megfigyelés (Coudevylle és mtsai, 2008a), a kísérlet (Rhodewalt, Tragakis és Finnerty, 2006) vagy éppen az interjú (Ferrand, Tetard és Fontayne, 2006). 


\section{ÖSSZEFOGLALÁS}

Tanulmányunkban az önakadályozás kérdéskört jártuk körbe. Bemutattuk az önakadályozás fogalmát, a fogalom hasonlóságait és különbségeit más rokon fogalmakkal, az önakadályozás jelenségének megjelenési formáit és a háttérben meghúzódó motivációkat, az önakadályozást elôidézô és gátló tényezôket, az önakadályozás elônyös és elônytelen következményeit és röviden kitértünk a mérés kérdésére is.

Az önakadályozás jelenségét úgy határoztuk meg, mint egy olyan cselekvés vagy teljesítményhelyzet-választás, amely növeli a kudarc externalizálásnak (önfelmentés), és a siker internalizálásának az esélyét (Jones és Berglas, 1978). Az önakadály olyan, az egyén által felállított akadály, amely hátráltatja eredményességét, így kudarc esetében a kudarc okává válik, míg siker esetében a siker e gátló tényezô ellenére áll elô. Ebbốl a fogalommeghatározásból számos kérdés adódik, a válaszokkal pedig a szakirodalom egyelőre adós marad. Tudatosan választott, stratégiai jellegú jelenségrôl van-e szó, amely a szelf-prezentáció egyik eszköze (Kolditz és Arkin, 1982; Prapavessis, Grove és Eklund, 2004),vagy egy önbecsapás alapon múködô védekezố reakcióról, amellyel a bizonytalan és alacsony önértékelést lehet védeni. Ez azért is jelentôs kérdés, mert - ahogy a mérésrôl szóló részben láthattuk - az önakadályozás irodalmának nagy része expliciten vagy impliciten azzal a feltételezéssel él, hogy a vizsgálati személyek képesek beszámolni az általuk használt önakadályokról, így a jelenség mérhetô kérdőívek segítségével. Amennyiben bebizonyosodna, hogy az önakadályok többsége önbecsapás alapon múködik, az megkérdôjelezné a kérdőíves módszerek használatának érvényességét. Ugyancsak a szakmai diskurzus tisztázatlan kérdése, hogy az önakadályozás inkább vonás vagy állapot jellegú jelenség, vagy olyan jelenség, amelynek van vonás- és állapotjellegú formája is. Az erre vonatkozó fejezetben számos olyan szituatív tényezôt számba vettünk, amely az önakadályozás megjelenésének valószínûségét növeli, vagy éppen csökkenti, miközben úgy tûnik, hogy „kétségtelen, hogy néhány ember hajlamosabb önakadályozó stratégiákhoz nyúlni, mint mások” (Berglas és Jones, 1978, 406). A személyes és szituatív tényezôk kutatása azért is különösen fontos, mert ez hozzásegíthet a sikeres preventív módszerek kidolgozásához. A szituatív tényezók kutatása azt mutatja, hogy a külsố elvárások - például a feladathelyzettel kapcsolatos célok (Midgley és Urdan, 2001) - vagy éppen a feladat elôtt elhangzó verbális közlések (Thürmer és mtsai, 2013) - befolyásolják az önakadályok felállítását, a személyes tényezôk esetében pedig sokszor csapdás helyzetekkel találkozunk. Az alacsony és bizonytalan önértékelés például önakadályozáshoz vezet, amely - fóleg ha viselkedéses önakadályról van szó - növeli a kudarc valószínúségét, ami aztán tovább rontja az önértékelést, így fokozva a védekezô reakciók megjelenésének valószínûségét. Szintén több vizsgálatot igényel a viselkedéses önakadályozásban megfigyelhetố nemi különbség magyarázata. McCrea és munkatársai (2008a; 2008b) vizsgálataikban meggyôzó eredményre jutottak, azonban tanulmányaikban csak az erôfeszítés hiányát vizsgálták. A témában nyitott kérdések megválaszolását nehezíti, hogy az egyes empirikus eredmények összehasonlítása nem egyszerû amiatt, hogy az egyes vizsgálatok különbözôképpen operacionalizálják az önakadályozást.

Az elméleti és empirikus szakirodalom véleményünk szerint egyik, a gyakorlat számára leginkább használható része - legyen szó akár iskolapszichológiáról, sportpszicho- 
lógiáról, klinikai pszichológiáról - éppen a szituáció és a személyiség szintjein megfogalmazható beavatkozások lehetôsége, amelyek csökkentik az önakadály felállításának szükségességét, és ezzel valószínúségét. Kearns, Forbes és Gardiner (2007) egy 5 héten át tartó kognitív-behaviorista coaching módszerrel való beavatkozássorozattal képesek voltak csökkenteni az önakadályozás szintjét. A módszer 5 fố lépésból áll: célállítás („hétfönként 2 órát olvasással fogok tölteni”), nehézségek azonosítása („gyakran facebookozás a vége”), költségek és ráfordítások („frusztráltnak érzem magam, kétlem, hogy sikerül”), cselekvés (a kitûzött cél teljesítésére való próbálkozás), hiedelmek azonosítása („milyen gondolataim voltak, amikor nem sikerült, hogyan segítenek ezek?”). Ezek a szisztematikus preventív beavatkozások azért is fontosak, mert az önakadályozás szakirodalmának többsége annak hosszú távú negatív következményeire hívja fel a figyelmet, amelyet nem ellensúlyoz a rövidtávon megszerezhetô, csekély számú elốny.

Az önakadályozás hazai vonatozásait vizsgálva az látható, hogy kevés magyar nyelvú tanulmány foglalkozik a témával (Hirt és McCrea, 2006; Rhodewalt és Tragakis, 2006; Forgács, 1994; Takács, 2010; Vargha és Mészáros, 2008). Már a jelenség magyar nyelvú megnevezésében is vannak viták, hiszen egyaránt használják az önkárosítás, önbénítás, önakadályozás és önakadályoztatás kifejezéseket. Mi az önakadályozást javasoljuk, hiszen míg a viselkedéses önakadályok valóban lehetnek önkárosítók, önbénítók, a mondott akadályoknál ez már nem jelenthetô ki egyértelmúen. Az önakadályoztatás kifejezés ugyan amiatt találó, hogy benne foglaltatik a másokkal való kapcsolat is, de nem szerencsés abból a szempontból, hogy azt sugallja, mintha ez az akadályozás mások által történne. A kevés számú magyar vizsgálat szerintaz önakadályozásra való hajlam pozitív kapcsolatban van a vonásként értelmezett félénkséggel, a külsô attribúciós stílusokkal és az emóciófókuszú megküzdéssel, negatív kapcsolatban az önértékeléssel, továbbá félénk vizsgálati személyek szignifikánsan több viselkedéses önakadályozásban vesznek részt az ellentétes nemú személyekkel történô interakciók során, mint kevésbé félénk társaik (Vargha és Mészáros, 2008). Török és munkatársai (2015) magyar mintán végzett vizsgálatukban azt találták, hogy a vonásként értelmezett önakadályozás pozitív kapcsolatban van a vonásszorongással, a szégyenre való hajlammal és az externalizálással, míg negatív a kapcsolata a rezílienciával, a szociális kívánatossággal és az önértékeléssel.

Összefoglalónkat hiánypótló munkának tekintjük figyelembe véve a külföldi publikációk sokaságát és a hazai tanulmányok csekély számát. Az önakadályozás kutatását azért tartjuk fontosnak, mert az önakadályozás tragédiája, hogy bár az önakadályozó átmenetileg el tudja választani egymástól a saját képességeit és az esetleges negatív teljesítményt, a kudarcot, hosszú távon viszont az önakadályozás a valódi potenciál, a személyben rejlô lehetôségek elvesztésével járhat.

\section{IRODALOM}

Adler, A. (1929). Problems of neurosis: A book of case histories. London: Kegan, Paul, Trench, Truebner.

Akin, A. (2012). Self-handicapping Scale: A study of Validity and Reliability. Egitim ve Bilim-Education and Science, 37(164), 176-187. 
Alter, A. L., \& Forgas, J. P. (2007). On being happy but fearing failure: The effects of mood on self-handicapping strategies. Journal of Experimental Social Psychology, 43(6), 947-954.

American Psychiatric Association. (1987). Diagnostic and statistical manual of mental disorders (3rd ed., revised). Washington, DC: Author.

Ames, C. (1992). Classrooms: Goals, structures, and student motivation. Journal of Educational Psychology, 84(3), 261-271.

Arkin, R. M., \& Baumgardner, A. H. (1985). Self-handicapping. In J. H. Harvey, \& G. Weary (Eds), Attribution: Basic issues and applications (pp. 169-202). New York: Academic Press.

Arkin, R. M., \& Oleson, K. C. (1998). Self-handicapping. In J. M. Darley, \& J. Cooper (Eds), Attribution and social interaction: The legacy of Edward E. Jones (pp. 313-371). Washington, DC: American Psychological Association.

Atkinson, J. W. (1964). An Introduction to Motivation. Princeton. NJ: Van Nostrand.

Bailis, D. S. (2001). Benefits of self-handicapping in sport: A field study of university athletes. Canadian Journal of Behavioral Science, 33(4), 213-223.

Bandura, A. (1986). Social foundations of thought and action: A social-cognitive theory. Englewood Cliffs, NJ: Prentice Hall.

Baumeister, R. F., \& Scher, S. J. (1988). Self-defeating behavior patterns among normal individuals: Review and analysis of common self-destructive tendencies. Psychological Bulletin, 104(1), 3-22.

Baumgardner, A. H., Lake, E. A., \& Arkin, R. M. (1985). Claiming mood as a self-handicap: The influence of spoiled and unspoiled public identities. Personality and Social Psychology Bulletin, 11(4), 349-357.

Berglas, S., \& Jones, E. E. (1978). Drug choice as a self-handicapping strategy in response to noncontingent success. Journal of Personality and Social Psychology, 36(4), 405-417.

Bobo, J. L., Whitaker, K. C., \& Strunk, K. K. (2013). Personality and student self-handicapping: A cross-validated regression approach. Personality and Individual Differences, 55(5), 619-621.

Brown, C. M., \& Kimble, C. E. (2009).Personal, interpersonal, and situational influences on behavioral self-handicapping. The Journal of Social Psychology, 149(6), 609-626.

Brown, J. D. (1991). Accuracy and bias in self-knowledge. In C. R. Snyder, \& D. F. Forsyth (Eds), Handbook of social and clinical psychology: The health perspective (pp. 158-178.). New York: Pergamon Press.

Burkley, H., \& Blanton, H. (2008). Endorsing a negative in-group stereotype as a self-protective strategy: Sacrificing the group to save the self. Journal of Experimental Social Psychology, 44(1), $37-49$.

Carron, A. V., Prapavessis, H.,\& Grove, R. J. (1994). Group effects and self-handicapping. Journal of Sport $\mathcal{E}$ Exercise Psychology, 16(3), 246-257.

Chen, L. H., Wu, C., Kee, Y. H., Lin, M., \& Shui, S. (2009). Fear of failure, 2x2 achievement goal, and self-handicapping: An examination of the hierarchical model of achievement motivation in physical education. Contemporary Educational Psychology, 34(4), 298-305.

Coudevylle, G. R., Gernigon, C., \& Martin Ginis, K. A. (2011). Self-esteem, self-confidence, anxiety and claimed self-handicapping. A meditational analysis. Psychology of Sport and Exercise, 12(6), 670-675.

Coudevylle, G. R., Martin Ginis, K. A., \& Famose, J.-P. (2008a). Determinants of self-handicapping strategies in sport and their effects on athletic performance. Social Behavior and Personality, 36(3), 391-398.

Coudevylle, G. R., Martin Ginis, K. A., Famose, J.-P., \& Gernigon, C. (2008b). Effects of self-handicapping strategies on anxiety prior to athletic performance. The Sport Psychologist, 22(3), 304-315. 
Covington, M. V. (1992). Making the grade: A self-worth perspective on motivation and school reform. Cambridge, England: Cambridge University Press.

Cox, C. B., \& Giuliano, T. A. (1999). Constructing obstacles versus making excuses: Examining perceiver's reactions to behavioral and self-reported self-handicapping. Journal of Social Behavior and Personality, 14(3), 419-432.

Crocker, J., \& Park, L. E. (2004). The costly pursuit of self-esteem. Psychological Bulletin, 130(3), 392-414.

De Castella, K., Byrne, D., \& Covington, M. (2013). Unmotivated or Motivated to Fail? A Cross-cultural Study of Achievement Motivation, Fear of Failure, and Student Disengagement. Journal of Educational Psychology, 105(3), 861-880.

DeGree, C. E.,\& Snyder, C. R. (1985). Adler's psychology (of use) today: Personal history of traumatic life events as a self-handicapping strategy. Journal of Personality and Social Psychology, 48(6), 1512-1519.

Deppe, R. K., \& Harackiewicz, J. M. (1996). Self-handicapping and intrinsic motivation: Buffering intrinsic motivation from the threat of failure. Journal of Personality and Social Psychology, $70(4), 868-876$.

Doliński D., \& Szmajke A. (1994). Samoutrudnianie. Dobre i zte strony rzucania kłód pod własne nogi. Pracownia Wydawnicza PTP, Olsztyn.

Doliński, D., Szmajke, A., \& Gromski, W. (1990). On the defensive function of own weaknesses: Self-handicapping strategy or excuses after failure? Polish Psychological Bulletin, 21(2), 157-165.

Drexler, L. P., Ahrens, A. H., \& Haaga, D. A. (1995). The affective consequences of self-handicapping. Journal of Social Behavior E Personality, 10(4), 861-870.

Dweck, C. S. (1986). Motivational processes affecting learning. American Psychologist, 41(10), 1040-1048.

Elliot, A. J., \& Church, M. A. (1997). A hierarchical model of approach and avoidance achievement motivation. Journal of Personality and Social Psychology, 72(1), 218-232.

Elliot, A. J., Cury, F., Fryer, J. W., \& Huguet, P. (2006). Achievement goals, self-handicapping, and performance attainment: a mediational analysis. Journal of Sport and Exercise Psychology, $28(3), 344-361$.

Elliot, A. J., \& McGregor, H. A. (2001). A 2 x 2 achievement goal framework. Journal of Personality and Social Psychology, 80(3), 501-519.

Feick, D. L., \& Rhodewalt, F. (1997). The Double-Edged Sword of Self-Handicapping: Discounting, Augmentation, and the Protection and Enhancement of Self-Esteem. Motivation and Emotion, 21(2), 147-163.

Fejes, J. B. (2011). A tanulási motiváció új kutatási iránya: a célorientációs elmélet. Magyar Pedagógia, 111(1), 25-51.

Fenigstein, A., Scheier, M. F., \& Buss, A. H. (1975). Public and private self-consciousness: Assessment and theory. Journal of Consulting and Clinical Psychology, 43(4), 522-527.

Ferrand, C., Tetard, S., \& Fontayne, P. (2006). Self-handicapping in rock climbing: A qualitative approach. Journal of Applied Sport Psychology, 18(3), 271-280.

Ferrari, J. R. (1992). Procrastination and perfect behavior: An exploratory factor analysis of self-presentational, self-awareness, and self-handicapping components. Journal of Research in Personality, 26(1), 75-84.

Ferrari, J. R., \& Thompson, T. (2006). Impostor fears: Links with self-presentational concerns and self-handicapping behavior. Personality and Individual Differences, 40(2), 341-352.

Ferrari, J. R., \& Tice, D. M. (2000). Procrastination as a self-handicap for men and women: A task avoidance strategy in a laboratory setting. Journal of Research in Personality, 34(1), 73-83.

Festinger, L. (1954). A theory of social comparison processes. Human relations, 7(2), 117-140. 
Finez, L., \& Sherman, D. K. (2012). Train in vain: the role of the self in claimed self-handicapping strategies. Journal of Sport $\mathcal{E}^{2}$ Exercise Psychology, 34(5), 600-620.

Finez, L., Berjot, S., Rosnet, E., \& Cleveland, C. (2011). Do athletes claim handicaps in low ego-threatening conditions? Re-examining the effect of ego-threat on claimed self-handicapping. The Sport Psychologist, 25(3), 288-304.

Flamm, A. (2007). When thinking means doing it: Prefactual thought in self-handicapping behavior. Unpublished doctoral dissertation. University of Konstanz, Germany.

Flett, G., Blankstein, K., Hewitt, P., \& Koledin, S. (1992). Components of perfectionism and procrastination in college students. Social Behavior and Personality, 20(2), 85-94.

Forgács J. (1994). Énattribúciók: A saját viselkedés értelmezése. In Forgács J., A társas érintkezés pszichológiáaja (pp. 114-131). Budapest: Gondolat Kiadó.

Freud, S. (1920). Jenseits des Lustprinzips [A halálösztön és az életösztönök]. Internationaler Psychoanalytischer Verlag, Leipzig-Wien-Zürich.

Gibson, B., \& Sachau, D. (2000). Sandbagging as a self-presentational strategy: Claiming to be less than you are. Personality and Social Psychology Bulletin, 26(1), 56-70.

Greaven, S. H., Santor, D. A., Thompson, R., \& Zuroff, D. C. (2000). Adolescent Self-Handicapping, Depressive Affect, and Maternal Parenting Styles. Journal of Youth and Adolescence, 29(6), 631-646.

Greenberg, J. (1985). Unattainable goal choice as a self-handicapping strategy. Journal of Applied Social Psychology, 15(2), 140-152.

Greenberg, J., Pyszczynski, T., \& Paisley, C. (1984). Effect of extrinsic incentives on use of test anxiety as an anticipatory attributional defense: Playing it cool when the stakes are high. Journal of Personality and Social Psychology, 47(5), 1136-1145.

Harris, R. N., \& Snyder, C. R. (1986). The role of uncertain self-esteem in self-handicapping. Journal of Personality and Social Psychology, 51(2), 451-458.

Hausenblas, H. A., \& Carron, A. V. (1996). The relationship between group cohesion and self-handicapping in female and male athletes. Journal of Sport E Exercise Psychology, 18(2), 132-143.

Hendrix, K. S., \& Hirt, E. R. (2009). Stressed out over possible failure: The role of regulatory fit on claimed self-handicapping. Journal of Experimental Social Psychology, 45(1), 51-59.

Higgins, R. L. (1990). Self-handicapping: Historical roots and contemporary branches. Individual differences in the preference for anticipatory, self-protective acts. In R. L. Higgins, C. R. Snyder, \& S. Berglas (Eds), Self-handicapping: The paradox that isn't (pp. 1-35). New York, NY: Plenum Press.

Higgins, R. L., \& Harris, R. N. (1988). Strategic alcohol use: Drinking to self-handicap. Journal of Social and Clinical Psychology, 6(2), 191-202.

Hirt, E. R., Deppe, R. K., \& Gordon, L. J. (1991). Self-reported versus behavioral self-handicapping: Empirical evidence for a theoretical distinction. Journal of Personality and Social Psychology, 61(6), 981-991.

Hirt, E. R., \& McCrea, S. M. (2006). Az önakadályoztatás elhelyezése az én-védelmi arzenálban. In J. P. Forgas, \& K. D. Williams (szerk.), A társas lény (pp. 122-148). Budapest: Kairosz Kiadó.

Hirt, E. R., McCrea, S. M., \& Boris, H. I. (2003). "I Know You Self-Handicapped Last Exam": Gender Differences in Reactions to Self-Handicapping. Journal of Personality and Social Psychology, 84(1), 177-193.

Hirt, E. R., McCrea, S. M., \& Kimble, C. E. (2000). Public self-focus and sex differences in behavioral self-handicapping: Does increasing self-threat still make it 'just a man's game?' Personality and Social Psychology Bulletin, 26(9), 1131-1141. 
Jones, E. E., \& Berglas, S. (1978). Control of attributions about the self through self-handicapping strategies: The appeal of alcohol and the role of underachievement. Personality and Social Psychology Bulletin, 4(2), 200-206.

Jones. E. E., \& Rhodewalt, F. (1982). The Self-handicapping Scale. Elérhetố a második szerzôtôl: F. Rhodewalt. Department of Psychology, University of Utah, Salt Lake City, UT.

Kearns, H., Forbes, A., \& Gardiner, M. L. (2007). A cognitive behavioural coaching intervention for the treatment of perfectionism andself-handicapping in a nonclinical population. Behaviour Change, 24(3), 157-172.

Kelley, H. H. (1971). Attribution in social interaction. New York: General Learning Press.

Kim, H., Lee, K., \& Hong, Y.-Y. (2012). Claiming the Validity of Negative Ingroup Stereotypes When Foreseeing a Challenge: A Self-Handicapping Account. Self E् Identity, 11(3), 285-303.

Kim, Y., Chiu, C., \& Zou, Z. (2010). Know thyself: Misperceptions of actual performance undermine achievement motivation, future performance, and subjective well-being. Journal of Personality and Social Psychology, 99(3), 395-409.

Kimble, C. E., Funk, S. C., \& DaPolito, K. L. (1990). The effects of self-esteem certainty on behavioral self-handicapping. Journal of Social Behavior and Personality, 5(3), 137-149.

Kimble, C. E., Kimble, E. A., \& Croy, N. A. (1998). Development of self-handicapping tendencies. The Journal of Social Psychology, 138(4), 524-535.

Kimble, C. R., \& Hirt, E. (2005). Self-focus, gender, and habitual self-handicapping: Do they make a difference in behavioral self-handicapping? Social Behavior and Personality, 33(1), $43-56$.

Kling, K. C., Hyde, J. S., Showers, C. J., \& Buswell, B. N. (1999). Gender differences in selfesteem: A meta-analysis. Psychological Bulletin, 125(4), 470-500.

Knee, C. R., \& Zuckerman, M. (1998). A nondefensive personality: Autonomy and control as moderators of defensive coping and self-handicapping. Journal of Research in Personality, 32(2), 115-130.

Kolditz, T. A., \& Arkin, R. M. (1982). An Impression Management Interpretation of the Self-Handicapping Strategy. Journal of Personality and Social Psychology, 43(3), 492-502.

Kraiem, S., \& Bertsch, J. (2011). Adaptation française d'une échelle d'auto-handicap: la Self-Handicapping Scale. Revue Internationale de Psychologie Sociale, 2(24), 5-31.

Leary, M. R., \& Shepperd, J. A. (1986). Self-handicapping: A conceptual note. Journal ofPersonality and Social Psychology, 51(6), 1265-1268.

Levesque, M. J., Lowe, C. A., \& Mendenhall, C. (2001). Self-handicapping as a method of selfpresentation: An analysis of costs and benefits. Current Research in Social Psychology, 6(15), $1-13$.

Luginbuhl, J., \& Palmer, R. (1991). Impression management aspects of self-handicapping: Positive and negative effects. Personality and Social Psychology Bulletin, 17(6), 655-662.

Lupien, S. P., Seery, M. D., \& Almonte, J. L. (2010). Discrepant and congruent high self-esteem: Behavioral self-handicapping as a preemptive defensive strategy. Journal of Experimental Social Psychology, 46(6), 1105-1108.

Maddison R., \& Prapavessis, H. P. (2007). Self-handicapping in sport: a self-presentation strategy. In S. Jowett, \& D. Lavallee (Eds), Social psychology in sport (pp. 209-220). Champaign, IL: Human Kinetics.

Martin, A. J., Marsh, H. W., \& Debus, R. L. (2003). Self-handicapping and defensive pessimism: A model of self-protection from a longitudinal perspective. Contemporary Educational Psycho$\log y, 28(1), 1-36$.

Martin, K. A., \& Brawley, L. R. (1999). Is the Self-Handicapping Scale reliable in non-academic achievement domains? Personality and Individual Differences, 27(5), 901-911. 
Martin, K. A., \& Brawley, L. R. (2002). Self-handicapping in physical achievement settings: The contributions of self-esteem and self-efficacy. Self and Identity, 1(4), 337-351.

McCrea, S. M. (2008). Self-Handicapping, Excuse Making, and Counterfactual Thinking: Consequences for Self-Esteem and Future Motivation. Journal of Personality and Social Psychology, 95(2), 274-292.

McCrea, S. M., \& Flamm, A. (2012). Dysfunctional anticipatory thoughts and the self-handicapping strategy. European Journal of Social Psychology, 42(1), 72-81.

McCrea, S. M., \& Hirt, E. R. (2001). The role of ability judgments in self-handicapping. Personality and Social Psychology Bulletin, 27(10), 1378-1389.

McCrea, S. M., \& Hirt, E. R. (2011). Limitations on the substitutability of self-protective processes: Self-handicapping is not reduced by related-domain self-affirmations. Social Psychology, 42(1), 9-18.

McCrea, S. M., Hirt, E. R., \& Milner, B. J. (2008a). She works hard for the money: Valuing effort underlies gender differences in behavioral self-handicapping. Journal of Experimental Social Psychology, 44(2), 292-311.

McCrea, S. M., Hirt, E. R., Hendrix, K. L., Milner, B. J., \& Steele, N. L. (2008b). The worker scale: Developing a measure to explain gender differences in behavioral self-handicapping. Journal of Research in Personality, 42(4), 949-970.

McCrea, S. M., Myers, A. L., \& Hirt, E. R. (2009). Self-handicapping as an anticipatory selfprotection strategy. In E. P. Lamont (Ed.). Social Psychology: New Research (pp. 31-53). Hauppuage, NY: Nova Science.

Mello-Goldner, D., \& Jackson, J. (1999). Premenstrual syndrome (PMS) as a self-handicapping strategy among college women. Journal of Social Behavior and Personality, 14(4), 607-616.

Mello-Goldner, D., \& Wurf, E. (1997). The self in self-handicapping: Differential effects of public and private audiences. Current Psychology, 15(4), 319-331.

Midgley, C., \& Urdan, T. (1995). Predictors of middle school students' use of self-handicapping strategies. Journal of Early Adolescence, 15(4), 389-411.

Midgley, C., \& Urdan, T. (2001). Academic self-handicapping and performance goals: A further examination. Contemporary Educational Psychology, 26(1), 61-75.

Milner, B. (2009). Individual Differences in Peer Relationships: The Role of Self-Handicapping. Saarbrücken: VDM Verlag.

Murray, C. B., \& Warden, R. (1992). Implications of self-handicapping strategies for academic achievement: A reconceptualization. Journal of Social Psychology, 132(6), 23-37.

Mushquash, A. R., \& Sherry, S. B. (2012). Understanding the socially prescribed perfectionist's cycle of self-defeat: A 7-day, 14- occasion daily diary study. Journal of Research in Personality, 46(6), 700-709.

Newman, L. S., \& Wadas, R. F. (1997). When stakes are higher: Self-esteem instability and self-handicapping. Journal of Social Behavior and Personality, 12(1), 217-232.

Nordbotten, T., Abrahamsen, F. E., \& Karlsen, J. (2012). Motivational Climate and Self-Handicapping in Elite Junior Golf. International Journal of Applied Sports Sciences, 24(1), 43-58.

Norem, J. K., \& Cantor, N. (1986). Defensive pessimism: „Harnessing” anxiety as motivation. Journal of Personality and Social Psychology, 51(6), 1208-1217.

Nurmi, J. E., Onatsu, T., \& Haavisto, T. (1995). Underachievers' cognitive and behavioral strategies - self-handicapping at school. Contemporary Educational Psychology, 20(2), 188-200.

Ommundsen, Y. (2001). Self-handicapping strategies in physical education classes: The influence of implicit theories of the nature of ability and achievement goal orientations. Psychology of Sport and Exercise, 2(3), 139-156.

Ommundsen, Y. (2004). Self-handicapping related to task and performance-approach and avoidance goals in physical education. Journal of Applied Sport Psychology, 16(2), 183-197. 
Park, S. W., \& Brown, C. M. (2014).Different perceptions of self-handicapping across college and work contexts. Journal of Applied Social Psychology, 44(2), 124-132.

Prapavessis, H., \& Grove, J. R. (1998). Self-handicapping and self-esteem. Journal of Applied Sport Psychology, 10(2), 175-184.

Prapavessis, H., Grove, J. R., \& Eklund, R. C. (2004). Self-Presentational Issues in Competition and Sport. Journal of Applied Sport Psychology, 16(1), 19-40.

Pulford, B., Johnson, A., \& Awaida, M. (2005).A cross-cultural study of predictors of self-handicapping in university students. Personality and Individual Differences, 39(4), 727-737.

Pyszczynski, T., \& Greenberg, J. (1983). Determinants of reduction in intended effort as a strategy for coping with anticipated failure. Journal of Research in Personality, 17(4), 412-422.

Rhodewalt, F. (1990). Self-handicappers: Individual differences in the preference for anticipatory, self-protective acts. In R. L. Higgins, C. R. Snyder, \& S. Berglas (Eds), Self-handicapping: The paradox that isn't (pp. 69-106.). New York, NY: Plenum Press.

Rhodewalt, F., \& Davison, J. (1986). Self-handicapping and subsequent performance: Role of outcome valence and attributional certainty. Basic and Applied Social Psychology, 7(4), 307-322.

Rhodewalt, F., \& Tragakis, M. (2002). Self-Handicapping and the Social Self: The Costs and Rewards of Interpersonal Self-Construction. In J. Forgas \& K. Williams (Eds.), The Social Self: Cognitive, Interpersonal, and Intergroup Perspectives (pp. 121-143). Philadelphia, PA: Psychology Press.

Rhodewalt, F., \& Tragakis, M. (2006). Önakadályoztatás és a társas én: a személyközi én-felépítés hozadéka és ára. In J. P. Forgas, \& K. D. Williams (szerk.), A társas lény (pp. 149-171). Budapest: Kairosz Kiadó.

Rhodewalt, F., Saltzman, A. T., \& Wittmer, J. (1984). Self-handicapping among competitive athletes: The role of practice in self-esteem protection. Basic and Applied Social Psychology, 5(3), 197-209.

Rhodewalt, F., Morf, C., Hazlett, S., \& Fairfield, M. (1991). Self-handicapping: The role of discounting and augmentation in the preservation of self-esteem. Journal of Personality and Social Psychology, 61(1), 121-131.

Rhodewalt, F., Sanbonmatsu, D. M., Tschanz, B., Feick, D. L., \& Waller, A. (1995). Self-handicapping and interpersonal trade-offs: The effects of claimed self-handicaps on observers' performance evaluations and feedback. Personality and Social Psychology Bulletin, 21(10), 1042-1050.

Rhodewalt, F., Tragakis, M. W., \& Finnerty, J. (2006). Narcissism and self-handicapping: Linking self-aggrandizement to behavior. Journal of Research in Personality, 40(5), 573-597.

Richards, H. D. B., Johnson, G., Collins, D. J., \& Wood, J. E. (2002). Predictive ability of self handicapping and self-esteem in physical activity achievement context. Personality and Individual Differences, 32(4), 589-602.

Ross, S. R., Canada, K. E., \& Rausch, M. K. (2002). Self-handicapping and the five factor model of personality: Mediation between neuroticism and conscientiousness. Personality and Individual Differences, 32(7), 1173-1184.

Ryska, T. A. (2002). Effects of situational self-handicapping and state self-confidence on the physical performance of young participants. The Psychological Record, 52(4), 461-478.

Schill, T., Morales, J., Beyler, J., Tatter, T., \& Swigert, L. (1991). Correlations between self-handicapping and self-defeating personality. Psychological Reports, 69(2), 655-657.

Schultheiss, O. C., \& Brunstein, J. C. (2000). Choice of difficult tasks as a strategy of compensating for identity-relevant failure. Journal of Research in Personality, 34(2), 269-277.

Schwinger, M. (2013). Structure of academic self-handicapping: Global or domain-specific construct? Learning and Individual Differences, 27, 134-143. 
Schwinger, M., Wirthwein, L., Lemmer, G., \& Steinmayr, R. (2014). Academic Self-Handicapping and Achievement: A Meta-Analysis. Journal of Educational Psychology, 106(3), 744-761.

Self, E. A. (1990). Situational influences on self-handicapping. In R. L. Higgins, C. R. Snyder, \& S. Berglas (Eds), Self-handicapping: The paradox that isn't (pp. 37-68.). New York, NY: Plenum Press.

Shepperd, J. A., \& Arkin, R. M. (1989a). Determinants of self-handicapping: task importance and the effects of pre-existing handicaps on self-generated handicaps. Personality and Social Psychology Bulletin, 15(1), 101-112.

Shepperd, J. A., \& Arkin, R. M. (1989b). Self-Handicapping: The moderating roles of public self-consciousness and task importance. Personality and Social Psychology Bulletin, 15(2), 252-265.

Shepperd, J. A., \& Arkin, R. M. (1991). Behavioral other-enhancement: Strategically obscuring the link between performance and evaluation. Journal of Personality and Social Psychology, 60(1), 79-88.

Shepperd, J. A., \& Socherman, R. E. (1997). On the manipulative behavior of low Machiavellians: Feigning incompetence to "Sandbag” an opponent. Journal of Personality and Social Psychology, 72(6), 1448-1459.

Siegel, P. A., \& Brockner, J. (2005). Individual and organizational consequences of CEO claimed handicapping: What's good for the CEO may not be good for the firm. Organizational Behavior and Human Decision Processes, 96(1), 1-22.

Siegel, P. A., Scillitoe, J., \& Parks-Yancy, R. (2005). Reducing the tendency to self-handicap: The effect of self-affirmation. Journal of Experimental Social Psychology, 41(6), 589-597.

Smith, T. W., Snyder, C. R., \& Handelsman, M. M. (1982). On the self-serving function of an academic wooden leg: Test Anxiety as a self-handicapping strategy. Journal of Personality and Social Psychology, 42(2), 314-321.

Smith, T. W., Snyder, C. R., \& Perkins, S. C. (1983). The Self-Serving Function of Hypochondriacal Complaints: Physical Symptoms as Self-Handicapping Strategies. Journal of Personality and Social Psychology, 44(4), 787-797.

Snyder, C. R., \& Higgins, R. L. (1988). Excuses: Their effective role in the negotiation of reality. Psychological Bulletin, 104(1), 23-35.

Snyder, C. R., Smith, T. W., Augelli, R. W., \& Ingram, R. E. (1985). On the self-serving function of social anxiety: Shyness as a self-handicapping strategy. Journal of Personality and Social Psychology, 48(4), 970-980.

Snyder, K. E., Malin, J. L., Dent., A. L., \& Linnenbrink-Garcia, L. (2014). The message matters: The role of implicit beliefs about giftedness and failure experiences in academic self-handicapping. Journal of Educational Psychology, 106(1), 230-241.

Spalding, L. R., \& Hardin, C. D. (1999). Unconscious unease and self-handicapping: Behavioral consequences of individual differences in implicit and explicit self-esteem. Psychological Science, $10(6), 535-539$.

Standage, M., Treasure, D., Hooper, K., \& Kuczka, K. (2007). Self-handicapping in school physical education: The influence of the motivational climate. British Journal of Educational Psychology, 77(1), 81-99.

Stewart, M. A., \& De George-Walker, L. (2014). Self-handicapping, perfectionism, locus of control and self-efficacy: A path model. Personality and Individual Differences, 66, 160-164.

Stone, J. (2002). Battling doubt by avoiding practice: The effects of stereotype threat on self-handicapping in White athletes. Personality and Social Psychology Bulletin, 28(12), 1667-1678.

Strube, M. J. (1986). An analysis of the self-handicapping scale. Basic and Applied Social Psychology, 7(3), 211-224. 
Swim, J. K., \& Sanna, L. J. (1996). He's skilled, she's lucky: A meta-analysis of observers' attributions for women's and men's successes and failures. Personality and Social Psychology Bulletin, 22(5), 507-519.

Takács, I. (2010) . A halogatás jellemzôii a felsôoktatásban. Unpublished manuscript, Eötvös Loránd University, Budapest.

Thompson, T. (2004). Re-examining the effects of noncontingent success on self-handicapping behaviour. British Journal of Educational Psychology, 74(2), 239-260.

Thompson, T., \& Hepburn, J. (2003). Causal uncertainty, claimed and behavioural self-handicapping. British Journal of Educational Psychology, 73(2), 247-266.

Thompson, T., \& Richardson, A. (2001). Self-handicapping status, claimed self-handicaps and reduced practice effort following success and failure feedback. British Journal of Educational Psychology, 71(1), 151-170.

Thürmer, J. L., McCrea, S. M., \& Gollwitzer, P. M. (2013). Regulating self-defensiveness: If-Then plans prevent claiming and creating performance handicaps. Motivation and Emotion, 37(4), $712-725$.

Tice, D. M. (1991). Esteem protection or enhancement? Self-handicapping motives and attributions differ by trait self-esteem. Journal of Personality and Social Psychology, 60(5), 711-725.

Tice, D. M., \& Baumeister, R. F. (1990). Self-esteem, self-handicapping, and self-presentation: The strategy of inadequate practice. Journal of Personality, 58(2), 443-464.

Török, L., \& Szabó, Zs. P. (2015). Perfectionism, self-handicapping and attribution of positive and negative events among athletes. Poster presented at the 14th FEPSAC European Sport Psychology Congress, Bern, Switzerland.

Török, L., Szabó, Zs. P., \& Boda-Ujlaky, J. (2015). Self-esteem, self-conscious emotions, resilience, trait anxiety and their relation to self-handicapping tendencies. Review of Psychology, 21(2), 123-130.

Tucker, J. A., Vuchinich, R. E., \& Sobell, M. B. (1981). Alcohol consumption as a self-handicapping strategy. Journal of Abnormal Psychology, 90(3), 220-230.

Twenge, J. M., Catanese, K. R., \& Baumeister, R. F. (2002). Social exclusion causes self-defeating behavior. Journal of Personality and Social Psychology, 83(3), 606-615.

Urdan, T. (2004). Predictors of Academic Self-Handicapping and Achievement: Examining Achievement Goals, Classroom Goal Structures, and Culture. Journal of Educational Psychology, 96(2), 251-264.

Urdan, T., \& Midgley, C. (2001). Academic self-handicapping: What we know, what more there is to learn. Educational Psychology Review, 13(2), 115-138.

Urdan, T., Midgley, C., \& Andreman, E. M. (1998). Classroom influences ones self-handicapping strategies. American Educational Research Journal, 35(1), 101-122.

Uysal, A., \& Knee, C. R. (2012). Low trait self-control predicts self-handicapping. Journal of Personality, 80(1), 59-79.

Uysal, A., \& Lu, Q. (2010). Self-handicapping and pain catastrophizing. Personality and Individual Differences, 49(5), 502-505.

Vargha J. L., \& Mészáros T. K. (2008). Az önbénító stratégiák heteroszociális interakciókban való alkalmazásának vizsgálata fiatalok esetében. Erdélyi Pszichológiai Szemle, 9(2), 121-138.

Want, J., \& Kleitman, S. (2006). Imposter phenomenon and self-handicapping: Links with parenting styles and self-confidence. Personality and Individual Differences, 40(5), 961-971.

Weary, G., \& Williams, J. P. (1990). Depressive self-presentation: Beyond self-handicapping. Journal of Personality and Social Psychology, 58(5), 892-898.

Weiner, B. (1985). An attributional theory of achievement motivation and emotion. Psychological Review, 92(4), 548-573. 
Weidner, G. (1980). Self-handicapping following learned helplessness treatment and the Type A coronary-prone behavior pattern. Journal of Psychosomatic Research, 24(6), 319-325.

Zahavi, A., \& Zahavi, A. (1997). The Handicap Principle: A Missing Piece of Darwin's Puzzle. New York: Oxford University Press.

Zuckerman, M., \& Tsai, F. F. (2005). Costs of self-handicapping. Journal of Personality, 73(2), 411-442.

Zuckerman, M., Kieffer, S. C., \& Knee, C. R. (1998). Consequences of self-handicapping: Effects on coping, academic performance, and adjustment. Journal of Personality and Social Psychology, 74(6), 1619-1628.

\title{
THE PSYGHOLOGY OF SELF-HANDICAPPING: A REVIEW
}

\author{
TÖRÖK, LILLA - SZABÓ, ZSOLT PÉTER - BODA-UJLAKY, JUDIT
}

Self-handicapping is a phenomenon, where, under certain conditions, people with given personality variables hinder and handicap their efficiency before improtant performance-requiring situations. Early in the study we precisely define self-handicapping and place it amid the psychological theories and the related social psychological ideas. We discuss in detail, the two forms of self-handicapping: behavioral self-handicapping and self-reported handicaps. We also touch upon the motivations behind these strategies. The study analyses at length the factors that affect self-handicapping, and classifies them among two dimensions: related to person or environment, facilitating or hindering. We discuss the consequences of self-handicapping, dividing them into advantageous and detrimental groups. While taking into account the measurement opportunities for self-handicapping, we also mention the questionnaire and the experimental methodology. The final summary discuss the investigational difficulties and the Hungarian relations.

Keywords: self-handicapping, self-protection, self-representation 